\title{
El bien común, esencia y función del Derecho
}

\author{
Lorenzo Peña y Gonzalo \\ Instituto de Filosofía del CSIC \\ lorenzo.pena@,csic.es
}

DOI: https://doi.org/10.20318/eunomia.2018.4367

Agradezco efusivamente los estimulantes comentarios que consagran a mi libro, Visión lógica del Derecho —en lo sucesivo VLD_, los profesores Julia Barragán, Andrés Ollero, Manuel Atienza, Mariano Melero, Alfonso García Figueroa, Marcelo Vásconez y José Juan Moreso.

No pudiendo venir meticulosamente abordados en esta respuesta global sus minuciosos análisis, me disculpo por soslayar, en las páginas que siguen, muchos de los problemas contenidos en sus comentarios.

\section{Justicia y bien común}

Antes de entrar en la lectura desglosada de los comentarios, desearía hacer unas consideraciones sobre un problema recurrente: bien común frente a justicia. (V. Peña, 2016.)

Desde diversas perspectivas se me objeta que, si —en la fundamentación del Derecho- invocar el bien común no equivale a invocar la justicia, entonces no es acertado mi planteamiento, pues el valor supremo del Derecho es, precisamente, la justicia, sin que pueda venir ocupado ese sitial por otro valor (si es que es verdaderamente otro).

De modo general, mi reacción es que, mientras que la justicia es formal, el bien común es material. El bien común es un contenido, un bien. Una normativa en aras de la realización de un qué — concretamente el bien, cierto bien, el bien comúndifiere de una normativa que sólo se proponga la realización de un cómo, o sea: que aquello que venga realizado se lleve a cabo de una determinada manera - a saber: con justicia-.

Es bien sabido que Kant diferenció la normativa en aras del bien de aquella que se hace en aras de la rectitud. Para el filósofo de Königsberg el bien es asunto privado y empírico, un fin que cae fuera de la racionalidad jurídica. Ésta sólo regularía la manera como se relacionen los actos voluntarios de un sujeto con los de los demás (buscando cada uno los fines que desee), y esa manera es la regla de ejercitar la propia libertad de tal suerte que se armonice con la libertad de los demás según una ley universal.

En nuestro tiempo, Rawls ha retomado esa idea de Kant, dándole un nuevo perfil. Pienso que una magistral respuesta a su enfoque la brinda Michael Sandel 
(Sandel, 1998), especialmente en el apartado «Contesting the priority of the right over the good». Falla la pretensión de erigir a la justicia o la rectitud como lo único socialmente vinculante en la esfera pública, dejando a la privada de cada cual entender como quiera los fines de la vida (lo que para cada ciudadano particular sea el bien). Falla por varios motivos, entre otros que las reglas de rectitud sólo cobran sentido y motivación cuando se comparten algunos fines comunes, un bien común (además de que los particulares pueden y suelen tener igualmente concepciones muy diversas de la rectitud o justicia; de hecho es verosímil que la mayoría de nosotros discrepemos de la concepción rawlsiana).

La justicia es un canon de paridad o de proporcionalidad. Ha solido enunciarse como la máxima de tratar igual los casos iguales y de modo desigual los casos desiguales. Es atinada la discusión que de ese canon ofrece H.L.A. Hart (Hart, 1961) en el apartado «Principles of justice». Perfílase con nitidez en esas páginas de su obra cómo la justicia es esencialmente formal, deslindándose, escrupulosamente, la justicia de la ley y la justicia en la aplicación de la ley. La segunda está erizada de menos dificultades (no es que no presente ninguna), pero es un enigma en qué consista la justicia de la ley. En efecto: «tratar igual los casos iguales» es claramente un sintagma elíptico, sobreentendiéndose el adverbio "relevantemente». Y ¿qué es lo relevante? V.g. existía en Francia un impuesto sobre la fortuna (v. infra, el último apartado de este ensayo); en la actual presidencia ha venido reemplazado por uno sobre la fortuna inmobiliaria. ¿Vulnera la justicia tal cambio legislativo? Puede pensarse que sí, porque lo relevante es la capacidad económica del obligado tributario, esté invertida en lo que esté; puede creerse que no, porque en el nuevo impuesto lo relevante es el patrimonio inmobiliario, no el valor monetario de lo que uno tenga.

Asimismo, el actual impuesto español de la renta personal separa la renta llamada "del ahorro» de la del trabajo o actividad profesional; ésta sufre mayor progresividad y tipos impositivos más elevados. ¿Se están tratando de manera igual los casos relevantemente iguales?

Y ¿qué decir del trato desigual de los desiguales? Si el tipo máximo del recién mencionado impuesto es del $45 \%$, se aplica igual a dos rentas una de las cuales multiplica por mil o un millón a la otra. ¿Son relevantemente iguales o desiguales esas dos rentas para quedar sujetas al mismo tipo impositivo?

Dudo mucho que nos pueda sacar de dudas la mera aceptación del canon de justicia según lo he enunciado (o su sucedáneo de «dar a cada uno lo suyo»). Pero además, en esa célebre y añeja formulación falta tomar en cuenta la proporcionalidad. ¿Es justo que sustraer cierta suma esté penado con una privación de libertad de seis meses pero sustraer un euro más determine un salto de tipo, acarreando prisión de dos años? ¿Es justo que sea lícita la relación sexual con una persona pero — sin cambiar ninguna otra circunstancia- esté penalmente castigada con varios años de reclusión la relación con otra nacida 24 horas antes?

No sé cuál será el sentimiento del lector, pero el mío es que, aunque en esos ejemplos se están tratando de modo igual los iguales y desigual los desiguales, se comete injusticia, al infringirse el canon de proporcionalidad: se tratan de manera absolutamente diversa supuestos de hecho casi iguales. Conque tal vez podríamos preferir una definición diversa de la clásica: lo justo es tratar de manera similar los casos (relevantemente) similares.

Claro que quedan sin despejar varias incógnitas. A menudo va a ser difícil o imposible atenerse a tal principio. ¿Cómo regirse por el criterio de proporcionalidad 
cuando tengamos un constreñimiento del numerus clausus? Además, ¿qué rasgos son relevantes? ¿El grado de menesterosidad, el tiempo que se lleve en la cola, los méritos del beneficiario?

¿Qué regla de proporcionalidad habrá de escoger la ley para ser justa? P.ej., robar un millón de euros ¿habrá de estar penado con la mitad de reclusión que robar dos millones? ¿Cómo demostrar que el homicidio merece una pena tres veces mayor que el secuestro —o cualquier otra proporción que escoja el legislador penal?

La respuesta que sugiero a todas esas inquietudes es partir del bien común, llamando «justicia» al canon de atenerse, tanto en la legislación cuanto en la aplicación de la ley, a reglas de proporcionalidad acordes con el objetivo del bien común. La justicia pasa a ser así, en esencia, no arbitrariedad (cualquier desproporción implica un salto arbitrario).

Sin embargo, el bien común puede demandar que —en aras de otros valores asimismo requeridos por el bien común-, no siempre prevalezca ese canon. (Me remito de nuevo a Hart, pero también a I. Berlin, quien supo ver, mejor que nadie, la conflictividad entre diversos valores y derechos fundamentales.) Según mi concepción del Derecho Natural, centrada en el valor del bien común, puede ser válido edictar leyes injustas por mor de la concordia (de la paz social), o de la seguridad jurídica o de un mayor bienestar general.

Eso sucedió con la ley 46/1977 de 15 de octubre concediendo la amnistía. Una ley hoy muy atacada, olvidándose que, sin ella, no habríamos disfrutado del grado de convivencia en la diversidad que ha hecho posible una discusión académica como la que estamos ahora teniendo. Adúcese en su contra que vulnera la justicia. El diputado D. Antonio Carro pronunció en el Congreso un discurso opuesto al proyecto legislativo: "Operar con el concepto de amnistía, que borra el delito, para hechos atroces de muerte a sangre fría, implacables [...] puede resultar socialmente intolerable y gravemente pernicioso». $Y$ agregó: «Frente a los ataques a la democracia no es buena medicina la amnistía. La única medicina que aplican las democracias más genuinas y consolidadas es una estricta aplicación de la ley». (La ley se aprobó por 296 a favor, dos en contra, 18 abstenciones y uno nulo.)

Suele asociarse la exaltación de la justicia como valor supremo del Derecho (cuando no único) a la idea de que el ordenamiento jurídico sólo se ocupa de regular la convivencia entre los miembros de la sociedad de tal modo que se eviten los conflictos o, cuando surjan, se solventen con arreglo a pautas no arbitrarias. En su versión más radical, esa concepción lleva al Estado mínimo (policía más justicia penal).

Frente a eso está la realidad. Ningún Estado se ha limitado a las funciones mínimas que le reconocen los libertarios. Todos los Estados históricamente existentes se han encargado de dirigir el esfuerzo mancomunado de los miembros del cuerpo político para tareas encaminadas a la defensa, al servicio público y al fomento de la riqueza colectiva (v.g. las obras públicas, el abastecimiento de las poblaciones, el patrimonio arquitectónico público, etc.).

Por otro lado, esa concepción del Estado y del poder judicial, meros guardianes de la justicia, suele llevar aparejada una visión achatada del Derecho, como se echa de ver en los ejemplos de la mayoría de los jusfilósofos, generalmente ceñidos a las jurisdicciones penal y civil, desdeñando la contencioso-administrativa (hoy numéricamente preponderante). Desvanécese en ese enfoque la función del Derecho como normativa que implica obligaciones de los ciudadanos para con la 
comunidad y, correlativamente, derechos frente a esa comunidad. La mera palabra «convivencia» se entiende como coexistencia. (En verdad, sólo se convive si se hacen cosas juntos, si se tienen bienes en común.)

Sin bienes comunes difícilmente puede darse un bien común, el cual no es una suma de los bienes particulares. Una pluralidad de individuos en la cual todo fuera privado sería una mera yuxtaposición de átomos que espontáneamente entrarían en relaciones puramente particulares. Perdería así legitimidad (o nunca la adquiriría) la autoridad instituida para evitar o zanjar los conflictos, siendo entonces preferible un planteamiento acrático como el de Hans-Hermann Hoppe.

Los enfoques que estoy criticando parten de que la sociedad no tiene ningún fin (como no sea el puramente negativo de no agredirnos). Si la sociedad tiene un fin, éste ha de ser el bien común. Y el Derecho, la normativa reguladora de la sociedad, no puede perseguir un fin diverso del de la propia sociedad.

Vamos a concebir un país asiático donde, un tiempo atrás —como consecuencia, en parte, de su política legislativa-, la población vivía en la miseria, aunque disfrutando, eso sí, de una considerable dosis de igualdad social $-\mathrm{y}$, por lo tanto, de justicia social. Ya sé que para algunos autores - de inclinaciones más o menos libertarias- la justicia social no es justicia, porque la justicia, a secas, es igualdad ante la ley, al paso que la justicia social es una cierta igualdad de resultado que, precisamente, entraña una desigualdad ante la ley. A ese punto de vista cabe replicar que las necesidades humanas constituyen uno de los factores relevantes no el único- en la aplicación de los principios de tratar igual los iguales, o tratar similarmente los casos similares. En esa consideración se funda el Estado del bienestar que, mal que bien $-\mathrm{y}$ a pesar de los asaltos que sufre-, es una pauta parcialmente asumida por casi todas las legislaciones del mundo.

Volvamos a ese país asiático. Tras decenios de igual penuria, cambió su legislación, gracias a lo cual se ha fomentado la riqueza nacional, pero muy mal repartida. Imaginemos que ni siquiera se ha respetado el principio de diferencia de Rawls (p.ej. el $5 \%$ más pobre no ha visto mejorada su suerte, a diferencia del $95 \%$ restante). No sólo eso, sino que, dentro de ese $95 \%$, se han agravado considerablemente las desigualdades, lo cual ha elevado muchísimo los índices GINI tanto de riqueza cuanto de consumo y de renta.

Podríamos pensar que tales desigualdades no son injustas, porque ya se nos ha dicho que es justo tratar de modo igual los iguales y desigual los desiguales; incluso si alteramos tal concepto para tener en cuenta la proporcionalidad, quizá persiste el hecho de que los factores subyacentes se han diversificado, por lo cual sería justa la mayor desigualdad resultante. ¿Cuáles son esos factores subyacentes? ¿A qué ha de corresponder la renta? ¿A la capacitación, al esfuerzo, al mérito, a la necesidad, a la utilidad que reporta uno con su labor? Desde luego las necesidades de la gente no han sufrido esa variación. Incluso si se han producido acusadas diversificaciones de utilidad económica, muchos seguiríamos creyendo que las disparidades de bienestar derivadas implican mayor injusticia.

Pese a tal injusticia, casi todos viven mejor; no pocos, muchísimo mejor. La comunidad en su conjunto tiene un bienestar agregado muy superior al que tenía antes de las reformas: mejoría en la salud pública, mayor y mejor esperanza de vida, más prosperidad, mejores infraestructuras, mayores logros del país, más influencia en los asuntos mundiales. Existe, pues, un mayor bien común. Por consiguiente según el Derecho Natural —conforme con mi propuesta- la nueva legislación es preferible a la vieja. 
Eso sí, para aumentar el bien común, serán menester ulteriores reformas que redistribuyan la riqueza ya conseguida, porque, cæteris paribus, es preferible una sociedad con menores disparidades de bienestar (como lo supo ver y expresar admirablemente John Stuart Mill). Lleva razón Peter Turchin (el teórico de la ultrasociedad y de la evolución cultural) al sostener cuán vulnerables y frágiles son las sociedades muy inigualitarias: no sólo desmoralizan a los desfavorecidos socavando así la solidaridad social y la acción colectiva-, sino que, además, agudizan las rivalidades, incluso entre los privilegiados (Turchin, 2018). Turchin reconoce que hay ciclos históricos de nivelación y desnivelación; en ciertos períodos, el incremento del bien común acarrea mayor desigualdad; sólo que tal tendencia tiene que invertirse al alcanzarse cierto umbral, so pena de entrar en fase de involución, dañando ese mismo bien común.

Es compleja y sinuosa la relación entre el bienestar agregado de la población y la distribución igualitaria (justa), habiendo que distinguir la percepción individual de la decisión colectiva. Pensemos en la parábola de los jornaleros del Evangelio de San Mateo, 20, 1-16: el dueño de la hacienda paga igual a los braceros que han soportado la carga y el calor de toda la jornada que a aquellos que, contratados al caer la tarde, apenas han trabajado pocas horas. Indígnanse los primeros por tal injusticia (se tratan de manera igual los desiguales). El dueño replica que ha respetado su palabra y que no deben ser envidiosos. (Podría ofrecerse otro argumento: si los contratados más tarde han holgado durante la mayor parte del día, no ha sido por culpa suya.)

Cualquiera que sea nuestra opinión sobre esa paradójica parábola, es lo cierto que somos envidiosos y que nuestra espontánea reacción suele preferir que se nos trate justamente (en la visión que tengamos de lo que eso supone) antes que ver incrementado nuestro bienestar (o, peor, el bienestar común). Hay estudios que así lo demuestran. Cito los datos recopilados en Solnick \& Hemenway, 1998. Según una encuesta recogida en ese artículo, más de la mitad de los estudiantes renunciarían a ganar más si el incremento salarial estuviera condicionado a un descenso relativo en la escala retributiva dentro del establecimiento para el que trabajaran (o sea, si implicara un mayor aumento para sus compañeros de empleo).

Sólo que la racionalidad jurídica no es la suma de las preferencias desagregadas de los sujetos. (Recordemos la paradoja de la votación de Arrow.) Por eso la preceptividad del bien común no emana de que nuestra conciencia singular intuya su fuerza de obligar. Su vigencia es objetiva, no subjetivamente construida.

$$
* * *
$$

Paso ahora a hilvanar algunas reflexiones sobre los diversos comentarios.

Está impregnado de incitaciones intelectuales el que gentilmente dedica a mi obra Julia Barragán. Con su amplio conocimiento de temas relacionados con la teoría de la decisión racional, me interpela desde consideraciones epistemológicas de gran rigor, pero que -lamentablemente para mí- caen por entero fuera de mis campos de competencia. Ni la génesis del principio de incertidumbre de Heisenberg ni sus varias interpretaciones, ni su alcance ontológico ni sus consecuencias lógicas ni el recurso a una teoría de la probabilidad bayesiana son, para nada, temas en los cuales pueda yo emitir una opinión solvente. Me congratula ver que mi trabajo suscita cuestionamientos desde esos ángulos disciplinares.

Confieso, empero, cierto escepticismo con relación a una noción tan imprescindible como escurridiza: la probabilidad. Verdaderamente ¿ha demostrado alguien que se ajusta al teorema de Bayes el —vago y maleable- concepto de 
probabilidad que solemos manejar? (Un concepto cargado de paradojas, como lo supo analizar, años atrás, Andrés Rivadulla.) Personalmente prefiero usar adjetivos menos comprometidos con una teorización tan estricta, como "plausible» o «verosímil» - sin ignorar que no parecen haber tenido mucho éxito los intentos de $\mathrm{N}$. Rescher y de Karl Popper de formalizar sendos conceptos.

Hasta donde alcanzo a ver, el problema de la verosimilitud se les plantea a los jueces a la hora de formarse una opinión sobre los supuestos de hecho, sin que tenga yo claro que también sea apropiado para saber qué norma es aplicable (salvo en tanto en cuanto ello dependa de cuáles sean los supuestos fácticos). No desconozco que en el Derecho los hechos entran jurídicamente calificados (para venir adecuadamente subsumidos en supuestos fácticos de las normas) y que la calificación jurídica es una operación diversa de determinar la consecuencia jurídica. Me resisto, no obstante, a aceptar la visión que nos propone Julia de la decisión judicial, que sería un acto de voluntad, no de entendimiento, aunque de una voluntad racionalmente orientada por una interactiva consideración de normas y pruebas fácticas (testimonios, documentos, etc.). Confieso que en esa descripción no hallo pauta alguna para aclararme sobre qué deben hacer los jueces.

En mi propio planteamiento están deslindadas cinco operaciones. $1^{\text {a }}$ Averiguar los hechos, p.ej. que se ha dado tal relación sexual entre $A$ y $B$ en tales circunstancias. $2^{a}$ Calificarlos jurídicamente (si ha sido estupro, violación o relación libremente consentida). $3^{a}$ Indagar otras circunstancias fácticas, como eximentes, atenuantes y agravantes, que vendrían a integrarse en el supuesto de hecho jurídicamente calificado (así como, eventualmente, causas de impunibilidad o de prescripción). $4^{\text {a }}$ Interpretar los preceptos legislativos aplicables (en este caso el Código Penal). Y $5^{\mathrm{a}}$ Derivar la consecuencia jurídica, aplicando un principio de la lógica nomológica (el de la consecuencia jurídica) más la legislación vigente. Si la probabilidad o verosimilitud interviene en las tres primeras operaciones, dudo que esté presente en la cuarta.

Para mí, la actuación judicial es cognoscitiva, por mucho que se llame «decisión». Es verdad que el juez profiere «Debo condenar y condeno» o «Debo absolver y absuelvo»; trátase, empero, de fórmulas estereotipadas de la jerga forense, pragmáticamente sustituibles por otras sin verbos performativos («el acusado debe ser condenado y cumplir tal pena», p.ej.)

No se me escapan las dificultades de mi abordaje cognoscitivista de la decisión judicial. En particular, ¿cómo tildar de cognoscitivo el fallo por el cual el juez obliga al ofensor a pagar al agraviado una suma de 7500 euros en concepto de reparación por daños morales? ¿O incluso aquel en que determina que el perpetrador del delito purgará una pena de siete años de reclusión —en lugar de seis u ocho? En definitiva ¿qué se hace el arbitrio judicial? Tema para un libro. (V. Nieto, 2000.) Limítome aquí a decir que, en todos esos casos, el juez aplica un concepto de probabilidad sobre el supuesto de hecho (con todas sus circunstancias); a lo así (en parte) conjeturado corresponde -en virtud de la Ley- determinada consecuencia jurídica que el juez enuncia (o pronuncia).

Por consiguiente, la sentencia puede ser acertada o errónea. Ciertamente mi gradualismo me lleva a oponerme a la tesis de Dworkin de la única solución posible, averiguable por el Juez Hércules - y en eso coincido plenamente con Julia. A menudo los hechos son jurídicamente calificables así, en vez de asá, en algún grado, pero también viceversa, habiendo, por ello, dos normas aplicables, en mutuo conflicto. Habrá que estar a los grados de aplicabilidad respectivos - y también a los grados de vigencia- para determinar qué norma es exequible. Pero las no exequibles no dejan por ello de ser jurídicamente válidas. 
Esta descripción coincide en parte con la de Julia, pero deslindando las cinco operaciones efectuadas por el juez y haciendo estribar en la gradualidad la ausencia de una solución única.

También con relación al bien común coincido con Julia en que, por sí solo, no puede zanjar los dilemas. En mi libro me adhiero al pluralismo axiológico de I. Berlin, porque, siendo el bien común plurifacético, esas facetas pueden y suelen entrar en conflicto. No es fácil saber cuál es el mayor bien común, cuenta habida de todo (si costear el tratamiento terapéutico experimental o reservar los escasos recursos sanitarios para dolencias que sufren la mayoría de los pacientes). Sin duda también interviene aquí la probabilidad. Afirmo rotundamente en mi obra: son corolarios del bien común los derechos de libertad y los de bienestar, pero muchas veces colisionan.

Más que ahondar en la noción del bien común (tarea que he preferido dejarle a la filosofía política), me he atenido a una noción genérica, con unos pocos rasgos que ya he ido perfilando más arriba. Rara vez aducirá el juez directamente, en sus fundamentos jurídicos, el axioma del bien común (sobre todo porque las constituciones modernas no suelen mencionarlo). Hay casos, no obstante, en los que puede y debe hacerlo (siempre que la conciencia jurídica le sea propicia); p.ej. pronunciamientos jurisprudenciales contra legem por el principio del bien común. De hecho no es raro que así operen los jueces, aunque enunciándolo con otras palabras -y no siempre con acierto.

Es muy acertado, a mi modo de ver, el enfoque dado a su texto por Andrés Ollero: cotejar y contrastar dos jusnaturalismos, el suyo y el mío, indagando las convergencias y las divergencias. Una confrontación tanto más provechosa cuanto que ambos nos hallamos en una minoría dentro de una minoría. Primero nos ubicamos ambos en el jusnaturalismo -aunque Andrés con reservas y alguna reticencia, mientras que yo con entusiasmo y sin restricciones-; mas el jusnaturalismo es muy minoritario, hoy por hoy, en el área de la filosofía jurídica académica de habla hispana. Dentro de esa minoría, hay líneas con más seguidores (como pueden serlo el tomismo heredado y el neotomismo de Finnis), líneas que no seguimos ninguno de los dos, formando así el exiguo club de los calificables como «otros jusnaturalistas» —entre los cuales también figura A.E. Pérez Luño.

Pues bien, el jusnaturalismo independiente que Ollero colaciona con el mío empieza expresando su vacilación en cuanto a la autocalificación: «a estas alturas no sé si yo mismo puedo considerarme iusnaturalista». Mi opinión es que sí, como lo demuestra el texto sobre el cual estoy reflexionando. Sólo que se trata de un jusnaturalismo tan flexible y circunspecto que, a la postre, parece asimilable por un positivista no cerril. En cambio me ufanaría yo en la convicción de que el mío no hallará puertas abiertas en ninguna morada juspositivista, sino, a lo sumo, un cortés saludo desde la ventana. $Y$ no es que abrace yo un jusnaturalismo de rompe y rasga, un enfoque deliberadamente iconoclasta o rupturista. Ollero señala oportunamente la cautela y moderación a las cuales suelen conducir las argumentaciones de mi libro, según se van desarrollando y matizando (más allá de frases sueltas que, en aislamiento, podrían resultar altisonantes). Pero $\mathrm{mi}$ jusnaturalismo (preponderantemente) aditivo afirma la vigencia jurídica de normas perpetuamente válidas anteriores a los promulgamientos del legislador. Esa tesis jamás podría ingresar en la sala de visitas de una casa positivista que se precie.

En lugar de esas normas, el profesor sevillano perfila sutilmente en su comentario una visión diversa del Derecho Natural. Primero, al aseverar que no está 
formado por normas, sino por principios, piezas del Derecho con valor orientativo y programático. Segundo, al entenderlo «como el motor del Derecho positivo, tanto en el momento legislativo como —aún más- en el judicial». Y tercero, al decir que el Derecho Natural «sólo existe [...] dentro del Derecho positivo». Esa triple dimensión del jusnaturalismo del Profesor Ollero inspira la perspectiva desde la cual va comentando diferentes aspectos de mi obra.

Es quizá decisiva la tercera dimensión (aunque inseparable de las otras dos). Yo no creo que el Derecho Natural exista sólo dentro del Derecho positivo. En rigor no existe nunca dentro del Derecho positivo. Existe dentro de un ordenamiento jurídico integrado por dos componentes (como, al analizar mi concepción, acertadamente lo percibe el Profesor Atienza [vide infra], señalando que es una visión dualista): el Derecho Natural y el positivo, que se combinan y que pueden colisionar. Sin Derecho Natural no hay Derecho positivo (porque lo único que otorga validez jurídica a los preceptos del legislador es la norma jurídico-natural del bien común más la circunstancia de que es ése el legislador adecuado, en tal sociedad, estando las cosas como están).

Pero sin Derecho positivo sí hay Derecho Natural. No son tan infrecuentes casos en los cuales se hallan una pluralidad de seres humanos desligados transitoriamente al menos- de sus habituales encuadramientos institucionales, viéndose así compelidos a constituir una sociedad original. ¿Hay alguna norma que rija esa sociedad de náufragos? Dos ejemplos espectaculares nos vienen a la mente. Uno es el estrellamiento, el 13 de octubre de 1972, de un avión uruguayo en un risco de la cordillera de los Andes, con 27 supervivientes que tardaron 72 días en ser rescatados. El otro ejemplo es el de los 33 mineros sepultados en la mina San José, región de Atacama, el 5 de agosto de 2010, durante 69 días. No se me oculta que esas sociedades no disuelven los vínculos jurídicos de los náufragos, pero sí los suspenden. De momento, hay que sobrevivir, ateniéndose, no a las leyes positivas, sino a normas de Derecho Natural. Ha de erigirse una autoridad, no por un regular funcionamiento de mecanismos, sino por un hecho de mayor carisma (primer tipo de legitimidad weberiana). En esas sociedades provisionales rige la regla jurídico-natural de que quien asuma la tarea de velar por el bien común edicte los preceptos adecuados para dicho fin -que, en esas circunstancias de emergencia, no es otro que la supervivencia colectiva e individual. (Huelga recordar aquí detalles ampliamente conocidos, que fueron sensacionales.)

En el siglo XXI tales situaciones están destinadas a durar muy poco, pero en tiempos pretéritos podían prolongarse de manera imprevisible. Recordemos el caso de los ochenta esclavos malgaches que sobrevivieron, inicialmente, al naufragio del 31 de julio de 1761 en el islote Tromelin. La desventura se prolongó quince años (al final sólo quedaban siete mujeres y un niño). No conocemos cómo se organizaron pero está claro que no se regían por ningún Derecho positivo.

Precisamente porque Ollero no entiende el Derecho Natural como un conjunto de normas sino como principios motores destinados principalmente a los jueces, le asigna la doble función de; (1) filtrar las leyes injustas —legislación negativa, si bien únicamente para aquellos tribunales a los cuales haya confiado esa tarea el Derecho positivo; y (2) servir de pauta hermenéutica. Es ésta segunda, creo, la función principal para Ollero. Por eso no me queda claro - según lo leo-que el legislador esté obligado a legislar para el bien común. (En especial colijo que para Andrés el poder constituyente no está subordinado al Derecho Natural ni, por lo tanto, tiene el deber de estatuir para el bien común.) 
Con eso está dicho lo esencial. Mi propia obra ve las cosas de otro modo, no siendo de extrañar que el académico sevillano note la diferencia. Para mí las normas de Derecho Natural (incluyendo los axiomas de la lógica nomológica) poseen vigencia erga omnes; también para el legislador. (Es más, sobre todo para el legislador. Y asimismo para el pueblo soberano, pues, como lo supo ver Juan Bodino, si los súbditos están sujetos a los mandamientos del soberano, éste lo está a la Ley Natural.) El propio Hobbes impone al soberano obligaciones en aras del bien común —al menos según algunas lecturas (v. Lloyd, 2009).

En ocasiones Ollero ha afirmado que los derechos humanos son jurídicos incluso (creí entender) donde no han venido positivizados. Pero entonces es que son preceptivos para el legislador. Leyendo hoy su comentario a mi libro me pregunto si mantiene la misma postura; si, a su modo de ver, el poder constituyente tiene deberes jurídicos.

Para Ollero el juez carece de potestad para suplantar al legislador legítimo. Pienso yo, por el contrario, que puede, suele y debe hacerlo - siempre que estén dadas las condiciones idóneas. Cuando el legislador ha legislado mal, el juez está habilitado por el Derecho Natural a enmendarle la plana (actuando, eso sí, con pies de plomo y muy atento al estado de la conciencia jurídica).

Uno de mis ejemplos favoritos es la jurisprudencia del Conseil d'État francés, el tribunal supremo de la jurisdicción contencioso-administrativa, el cual, a partir de la Liberación (1944), ha venido pronunciando nuevos principios generales del Derecho que, en rigor, constituyen genuinas edicciones con valor legislativo. Así: el derecho a que se respete el principio de confianza legítima - lo cual exige que toda norma con efecto retroactivo incluya disposiciones transitorias; el derecho al recurso; el derecho a una norma lo menos onerosa posible que resulte compatible con los legítimos fines de la administración; el derecho, en los expedientes administrativos, a ser oído y a defender los propios intereses; el derecho de los servidores públicos a la reclasificación profesional; el derecho al respeto personal después de la muerte.

Ya antes la jurisprudencia francesa había edictado la prohibición del abuso del derecho (prohibición que colisionaba con todas las leyes que habían establecido derechos sin someterlos, para nada, a tal restricción).

No es que los tribunales estén llenando vacío legal alguno. Cuando sientan tal jurisprudencia con sus pronunciamientos, crean situaciones jurídicas generales (normas) que entran en contradicción con las previamente creadas por el legislador. Es verdad que el legislador puede edictar posteriormente leyes que anulen esos pronunciamientos jurisprudenciales (el sistema reconocido de fuentes sitúa las leyes por encima de los principios generales del Derecho). Pero raras veces se ha atrevido a hacerlo.

También los tribunales constitucionales han desbordado, desde hace tiempo, la misión de meros guardianes de la constitución en el doble sentido de legislación negativa y potestad hermenéutica. En (Figueruelo Burrieza, 1993) detállanse varios procedimientos por los cuales nuestro Tribunal Constitucional se ha visto llevado a lo que - ateniéndose estrictamente a los textos legislativos- sería una extralimitación. P.ej., las recomendaciones al legislador para subsanar sus omisiones y las sentencias aditivas o constructivas, las cuales - en palabras de la autora recién citada- son «una técnica de decisión cuyo fin es la transformación del significado de una ley sometida a control, antes que su eliminación o interpretación conforme a la Constitución» y «suponen una función positiva o integradora». ¿De qué fuerza vinculante están revestidas? Sobre tal cuestión tiene la palabra el propio magistrado 
Andrés Ollero, quien no es, como yo, mero espectador, sino un calificado agente jurídico, precisamente al máximo nivel.

Es Bélgica el país donde el poder judicial ha sido más audaz en sancionar al legislativo. El 28 de septiembre del 2006 la Corte de casación (tribunal supremo) sentencia que los tribunales judiciales tienen la potestad de controlar si el poder legislativo ha legislado de manera adecuada o suficiente para permitir al Estado respetar sus obligaciones derivadas de una norma superior, v.g. un convenio internacional. En otra sentencia el mismo tribunal condena al Estado belga a indemnizar a un justiciable que, a causa de la no dotación de suficientes recursos presupuestarios, vio frustrado su derecho a un proceso sin dilaciones; lo que se sanciona es una omisión del poder legislativo. (V. Ergec, 2002)

Un último desacuerdo que me parece hallar entre las tesis del Profesor Ollero y las mías es el carácter del ordenamiento jurídico. En rigor entiendo que para Andrés no existe el ordenamiento jurídico. Hay, sí, normas emanadas por el legislador más una pauta de justicia, con valor jurídico-natural, completadas por el trabajo de la jurisprudencia. Por el contrario lo que yo sostengo es que sí existe el sistema jurídico, aunque no exento de antinomias. Ollero cita mi aserto de que «mi propuesta marca unas pautas de sistematización racional que [...] no ignoran la enorme complejidad de los actuales ordenamientos (en buena medida, es verdad, desordenados)» (final de la respuesta a la $4^{a}$ dificultad del capítulo $\mathrm{VI}$ ).

La clave de mi enfoque está en la locución «en buena medida». No es cuestión de todo o nada. El gradualismo contradictorial inspira mi propuesta jusfilosófica igual que antes había dado aliento a mis aportaciones a otros campos de la filosofía. Tenemos un ordenamiento parcialmente desordenado. El orden existe, es imprescindible; sin él la praxis jurídica sería un caos. Pero, lejos de ser perfecto ese orden en nuestros modernos Estados de Derecho, sucede al revés: la multiplicación de las fuentes y la hipertrofia de leyes (con pluralidad de legisladores, cuyos ámbitos no siempre están claramente deslindados) así como también de convenios internacionales (entre otras fuentes) han arruinado los ideales arquitectónicos del legalismo decimonónico. Todo es mucho más complicado. Ya no valen, o no bastan, los cánones de la derogatio por los cuales el legalismo soñó con soslayar las antinomias.

Muchísimo me agradan las afables indicaciones de Manuel Atienza sobre las coincidencias entre mi pensamiento jusfilosófico y el de grandes maestros como García Máynez, Hart, Ferrajoli, Radbruch, MacCormick, Nino y, sobre todo, el propio Atienza; así como, más lejos, Ihering. Yo no puedo ni siquiera soñar con un conocimiento tan hondo y solvente de esos jusfilósofos como el que posee el profesor asturalicantino. No ha sido en momento alguno intención mía ufanarme de novedad u originalidad. Sobre que no creo necesitarla, tales jactancias son ridículas. Conque, en la medida en que se dan esas convergencias, las asumo de óptimo grado, contentándome con la, ya de suyo, honrosa tarea de reformular - con un sesgo y un estilo que me vienen de mi vocación lógica- un acervo de ideas que no encajan ni en el positivismo ni tampoco en ciertas formas de jusnaturalismo, concretamente en el jusnaturalismo sustractivo.

Aquí, empero, he de pronunciar una dolorida autocrítica. A varios de los jusfilósofos recién mencionados no los he traído a colación en mi libro, ora por estar poco familiarizado con ellos, ora por tenerlos un tanto olvidados (v.g. Ihering y Radbruch). 
Confieso, en cambio, mi desasosiego por haber omitido a Eduardo García Máynez, cuyas obras fueron, durante años, mi lectura diaria de cabecera, justamente en los albores de mi nueva etapa intelectual como filósofo del Derecho (en la segunda mitad de los noventa). A ningún otro autor - de nuestro idioma o de cualquier otrohe dedicado tan afanoso y esmerado empeño como los que puse en el estudio de las obras del profesor mexicano. Ciertamente, mi propia construcción comparte con la de García Máynez su espíritu, no pocas de sus fuentes (p.ej. Platón y N. Hartmann), su esencial orientación racionalista, su método y, en buena medida, sus conclusiones. Efectivamente mis principios de lógica nomológica guardan acusada similitud con los del mexicano. (También se dan diferencias; posiblemente éstas, en parte, se deben más a la fecha de escritura que a una discrepancia de raíz.) No negaré que aquel estudio me queda, a estas alturas, un poco lejos, pues, en años más recientes, apenas he repasado ese tesoro, por lo cual, sepultado en mi memoria -mas habiendo impactado y orientado decisivamente mi formación y mis opciones-, no he reactualizado ese legado - que, desde hace varios lustros, se incorporó plenamente a mi aportación.

Atienza considera que mi propuesta es muy similar a su propio pospositivismo. Confieso (y lamento) no haber leído todavía Filosofía del Derecho y transformación social. Es verosímil que mi tratamiento de las nuevas tendencias jusfilosóficas (un poco en tropel) incurra en una descuidada amalgama, en un totum revolutum, sin deslindar un pospositivismo peculiar, como el de Atienza, del neoconstitucionalismo -ya de suyo un heteróclito conglomerado de posturas diversas. Quizá en lo que sigue acierte a enunciar un problema - para mí fundamental - con relación al cual temo que estemos en desacuerdo. Un desacuerdo que justificaría mi apreciación de que ese pospositivismo no se aparta del todo del positivismo. ¡Ojalá consigamos acercarnos más!

En cuestión de «ismos» sucede como con las marcas o los títulos. Ni Platón ni Aristóteles ni Leibniz acuñaron denominación distintiva para sus filosofías; otros lo hicieron por ellos. Tal vez la pretensión de usar un membrete llamativo sea una práctica académicamente inadecuada que se asemeja a una operación de marketing, un ánimo de diferenciar más que de converger en la busca de la verdad. Así y todo no deja de parecerme que una etiqueta como "pospositivismo» no ayuda a saber, a simple vista, de qué se trata. Y confieso que me recuerda demasiado la moda de los «pos» (posestructuralismo, posmarxismo, poscolonialismo, posmodernismo, posmetafísica y hasta posverdad), tan característica de la French Theory. ¿No es mejor definirse por lo que uno propone que por lo que deja atrás? Los destinatarios lo agradecerán y, creo, habrá mayor claridad en el debate.

Hay dos discrepancias entre la propuesta de Atienza — según él mismo nos la recuerda y esboza en su contribución - y la que he sostenido en VLD. Una de ellas es, verosímilmente, superable y acaso terminológica. La otra creo que no.

Empiezo por la segunda. Atienza mira con mucho recelo mi naturalismo jurídico (un naturalismo que me aparta —como él lúcidamente lo ve- de los otros jusnaturalistas, como no sea Ulpiano), o sea ver al hombre como una especie social, igual que otras, haciendo radicar la normatividad en una exigencia de la naturaleza de los seres sociales, ateniéndonos al adagio ubi societas, ibi jus. Él objeta que el Derecho es social e histórico y, por lo tanto, no natural. No cabría hablar de Derecho en sociedades no humanas (ni siquiera en sentido lato), porque tampoco habría Derecho en toda sociedad humana. Alega, a este respecto, los hallazgos de la etnografía. Sólo determinadas sociedades, como resultado de un previo devenir histórico, habrían generado Derecho. 
Ahora bien, esa tesis puede entenderse de dos modos. En un modo terminológico, sería una estipulación semántica de llamar "Derecho» sólo a un sistema de normas (o de prácticas) como las que conocemos en sociedades históricamente descritas o en algunas de ellas; un sistema con reglas hartianas de reconocimiento, legisladores, tribunales, interposición de recursos, leyes, tratados, contratos, jerarquía normativa y fuerza de la cosa juzgada; rasgos que, mal que bien, podríamos reconocer (a grandes trazos) desde Hamurabí para acá, pero seguramente no entre los esquimales, los mapuches o los pigmeos de Ruanda.

En otro modo, la tesis que estoy considerando sobre el origen del Derecho afirmaría que entre un sistema así y un conjunto de normas sin tales características no habría nada compartido que hiciera interesante subsumirlos bajo una común denominación.

Entiendo perfectamente el modo semántico de abordar esa dicotomía desde el enfoque atienciano, para el cual el Derecho no es un cúmulo de normas sino uno de prácticas. Tales prácticas no se dan en sociedades de las que solemos llamar «primitivas» - siendo dudoso si se dieron en sociedades humanas anteriores a las que conocemos por huellas escritas.

Que llamemos «Derecho» a un sistema de normas o a un conjunto de prácticas no carece, sin duda, de relevancia para nuestro tratamiento teorético de lo jurídico. Confieso mi preferencia por la primera opción porque me parece más acorde con el uso del vocablo. Cuando decimos «según el Derecho, los menores de 18 años no pueden votar» o «los tribunales sólo están sujetos a la ley y al Derecho» o «el juez no ha aplicado correctamente el Derecho» (más en general, cuando los estudios de política judicial cuestionan en qué medida las decisiones judiciales vienen determinadas por el Derecho); cuando hablamos así, está claro que nos referimos a las normas vigentes, no a las prácticas. Similarmente, decimos que, al concluir la carrera en la Facultad, se conoce Derecho, pero no se puede ejercer una profesión jurídica, porque falta aún familiarizarse con las prácticas jurídicas (p.ej. es menester una pasantía para ser abogado). Dudo que sea inocua esa divergencia terminológica (generalmente las opciones de nomenclatura no lo son). Pero, de momento, lo dejo aquí.

La razón por la que no comparto la dicotomía atienciana entre sociedades con y sin Derecho es que no veo motivo suficiente para rechazar la juridicidad de sistemas de normas menos alambicados, pero que funcionan y a partir de cuya evolución surgieron los nuestros.

Me resulta similar esa dualidad a la que tantos autores han querido establecer entre sociedades con y sin Estado. Engels sostuvo (en 1884) que el Estado surgió en el siglo VIII aEC (ateníase, claro, a los conocimientos de su tiempo, pero no parece haberlos ponderado adecuadamente -ni probablemente estaba muy al día). Para Alain Soupiot el Estado surge al final de la Edad Media (no habrían sido Estados los imperios chino, egipcio, asirio, cartaginés, persa, bizantino ni los reinos de la India ni el poder incaico). Idea central en la teoría política de Marcel Gauchet es la división de las sociedades entre las que tienen Estado y las que carecen de él (sin por eso dejar de ser políticas).

Resúltanme arbitrarios tales cortes. Dudo que, situando el presunto salto en un momento, $X$, sean muy distintas las sociedades del año precedente a $X$ de las del año siguiente. Idem con los respectivos sistemas normativos. Coincido, antes bien, con Santi Romano (justo ahora, cuando se cumplen cien años de la publicación de II ordinamento giuridico). Ciertamente el institucionismo del profesor palermitano tiene 
una cercanía con la visión atienciana del Derecho como conjunto de prácticas, no de reglas de acción.

Pero hay otra faceta de su aportación que la caracteriza todavía más: la de que cualquier sociedad, legal o ilegal, tiene una normativa que constituye un Derecho interno, incluso cuando se trata de organizaciones clandestinas que actúan contra el poder del Estado y desacatan su legislación. Aunque el jusfilósofo siciliano pensaba en bandas criminales que se erigen en Estado dentro del Estado, con mayor razón podríamos aplicar esa idea a asociaciones subversivas que no reconocen la legitimidad del régimen establecido. Sólo pueden existir si en ellas se adopta alguna normativa, expresa o tácita; $y$, según se desarrollan, suelen ir perfeccionando esa normativa, dotándola de algunos rasgos no tan distantes de los que adscribimos al Derecho propiamente dicho - 0 sea el de nuestras sociedades actuales.

En mi respuesta a los comentarios de $\mathrm{A}$. Ollero, más arriba, hablé de sociedades de emergencia cuyo surgimiento se ha debido a imprevisibles acaecimientos calamitosos. Ahora acabo de referirme a sociedades clandestinas voluntariamente creadas por individuos hostiles al ordenamiento jurídico-político existente: ora (a) por motivos crapulosos; ora (b) por causas ideológicas o similares. (Abundan los casos mixtos.) Topámonos también, empero, con sociedades mucho más estables, derivadas de las subversivas, sean del tipo (a), sean del tipo (b) o mixtas.

Atienza menciona ( $v$. infra) la insurrección de Espartaco (73-71 aEC). ¿Cómo olvidar que ésa y las dos grandes sublevaciones de esclavos que la precedieron $-\mathrm{y}$ que la superaron con creces en envergadura - (ambas en Sicilia: la de Euno, 135132 aEC, y la de Atenión y Trifón, 104-100 aEC) instituyeron sus propias sociedades rebeldes a Roma, lo cual requería asumir unas reglas de reconocimiento (expresas o tácitas) así como unas autoridades a cuyo cuidado quedara la comunidad (generalmente un jefe, a veces proclamado rey)? Tuvieron que inventar su propio Derecho positivo, pero su única guía para hacerlo era el Derecho Natural.

Mucho más extenso y arraigado fue el fenómeno del cimarronaje en las Américas de los siglos XVI al XIX, donde los negros que se alzaban o escapaban de la esclavitud constituyeron sociedades rebeldes: las unas, efímeras, meras bandas de fugitivos; las otras, duraderas, verdaderos micro-Estados, los palenques o quilombos, como el de Palmares en el Brasil, con una población de quince mil habitantes, que se mantuvo indómito durante casi un siglo. (V. Price, 1996).

Más recientemente tenemos las sociedades rebeldes en los países afroasiáticos sometidos al yugo colonial. Para muchos indígenas el infierno de la dominación europea no era, en absoluto, un legítimo ordenamiento jurídico, sino una invasión extranjera - aun mucho tiempo después de la conquista, como en la India. Cuando no eran fulminantemente sofocadas, tales insurrecciones conducían a menudo a la creación de "zonas liberadas» donde emergía un Derecho rebelde, el cual, para brotar, necesitaba una semilla, proporcionándola el Derecho Natural: un principio de bien común más unas pautas mínimas de racionalidad normativa.

Por otro lado, está la piratería, floreciente y masiva desde la Antigüedad, no pocas veces en confluencia con rebeliones de esclavos u otras. Podrían multiplicarse los ejemplos de sociedades irregulares.

Los etnógrafos están en lo suyo cuando se empeñan en trazar un cuadro muy diferenciador de las sociedades que ellos estudian -esas que ya hoy no podemos llamar «primitivas» (sin saber qué adjetivo políticamente correcto es el idóneo para 
denominarlas). Pero, sin negar que los Gadabas de Andhra Pradesh verosímilmente carecen de las estructuras con las que está familiarizado cualquier estudiante de Derecho, me resulta infundado rehusarles su propia juridicidad, distinta de la nuestra, sin duda más rudimentaria.

Necesito, para aceptar esa dicotomía entre sociedades con y sin Derecho, que se me aclaren varias incógnitas. Primera, ¿por qué es menester adoptar esa dualidad si no es un mero postulado de significación? Segunda, ¿qué rasgos concretos marcan la diferencia? Tercera, ¿hay algún tránsito paulatino de la carencia de Derecho a su existencia, o se da un salto? Cuarta, ¿qué factores determinan esa mutación abrupta o progresiva-? ¿Trátase de un acto bruto de voluntad? ¿Trátase de una mejora de pautas ya previamente institucionalizadas? ¿Es resultado de la evolución de las necesidades de una vida social más compleja?

Cualesquiera que sean las respuestas idóneas a sendas inquietudes, personalmente me inclino más a una concepción amplia del Derecho como un conjunto de normas con cierto orden que sirven para regular la convivencia de los miembros de una sociedad y su cooperación en aras del bien común. ¿Hay ontológicamente una diferencia sustancial entre una normativa así, acaso tosca, y la de un Estado moderno? Porque el desacuerdo no se refiere a si hay diferencia, sino a si es tal que no cabe subsumir ambas normativas bajo un común denominador.

Es ese común denominador lo que a mí me interesa, aquello que creo que incorpora, por necesidad natural, unos axiomas de ordenación para el bien común, tengan o no conciencia de ello los miembros de la sociedad o sus jefes.

A mi juicio ha sido gradual el paso de normativas rudas y exentas de refinamiento a otras inteligentemente elaboradas; no se ha producido por una decisión deliberada, sino por reflejo de las necesidades de la vida social.

Así pues, reconociendo, ciertamente, que el Derecho es una realidad social y que está sujeta al devenir histórico, no creo que sea un producto de la historia ni, menos aún, un producto de la voluntad humana, de los hombres de una determinada sociedad a los que súbitamente se les ocurre instituir un nuevo haz de prácticas, las que reconoceríamos como jurídicas. (Sería, digamos, el pacto social de Grocio, Hobbes, Locke o Rousseau, ridiculizado en 1741 por David Hume y más tarde por Adam Smith y J. Bentham.) Pienso que si, contrafácticamente, suponemos una decisión innovadora de adoptar instituciones jurídicas, ese acto instituyente requiere ser legítimo, en virtud de normas preexistentes. (¿Quién ha preceptuado pacta sunt servanda?) Lo cual nos retrotrae a la normativa anterior, más rudimentaria, pero adaptada a la sociedad de su época. ¿Por qué no verla como un ordenamiento jurídico primitivo?

Imaginando, alternativamente, que los hombres fueron inventando el Derecho poco a poco, sin darse cuenta, de manera espontánea, a cada paso en esa progresión le aplico el mismo razonamiento. En esta hipótesis no hay salto, de suerte que las instituciones normativas del año $X$ apenas difieren de las del año $X+1$, por lo cual encuentro arbitrario el brusco corte que da el teórico al fijar una línea o un punto tal que a un lado está el Derecho y al otro el no-Derecho.

Por otro lado dudo que los antropólogos estén todos de acuerdo en sostener que las sociedades - digamos - indígenas carecen de una normativa que quepa llamar «Derecho». En (Freeman \& Napier, 2009), los coordinadores del volumen afirman (pp. 2-3): 
Even in the twentieth century anthropologists using a folk rather than an analytic concept of law have been inclined to deny that simpler societies had law. [...] Bronisław Malinowki was critical of that type of ethnocentrism. It was wrong, he claimed, to define the forces of law in terms of 'central authority, codes, courts and constables' [...] Malinowski's 'minimal definition' of law was intended to have universal application.

Los dos autores anglosajones reseñan desarrollos más recientes de la antropología jurídica, que manejan conceptos del Derecho diversos del de Malinowski pero coinciden en reconocer que las sociedades que llamamos «primitivas» tienen Derecho -otro Derecho-, un Derecho esencialmente consuetudinario, en parte ritual, reglado (aunque no verbalmente enunciado), que no carece de sanciones institucionalizadas. También se han estudiado sociedades primarias donde existen bajo modalidades diferentes de las nuestras - juicios y órganos decisorios - v.g. consejos tribales. (Reconozco, sin embargo, que no faltan etnógrafos para quienes son intraducibles los conceptos de organización social de esas poblaciones, por lo cual se estaría haciendo violencia semántica al calificarlas de jurídicas o protojurídicas.)

Desde luego Atienza puede considerar que todos mis ejemplos se refieren a sociedades carentes de Derecho. Quizá hablamos de cosas distintas. Mi filosofía del Derecho es una filosofía aplicable a los sistemas normativos instituidos en sociedades humanas y revestidos de fuerza coercitiva; a todos, no sólo a algunos. Pienso que el profesor asturiano entiende su misión como la de brindar una filosofía jurídica apropiada a nuestro tiempo, a un Estado social y democrático de Derecho.

La otra discrepancia entre la propuesta atienciana y la mía me parece verosímilmente superable. A Manuel Atienza le duele mi radical separación entre ética y Derecho. Insiste en que se da una moral interna del Derecho, diversa de la moral de los individuos y los grupos, si bien entre la una y la otra hay continuidad. A este respecto se extraña de que yo, tan gradualista, adopte en este punto un enfoque estrictamente discontinuista o dicotómico.

Mi distingo entre Derecho y moral lo he formulado en mi libro con tal énfasis e hincapié que puedo haber llevado, sin quererlo, a que no sólo Atienza, sino cualquier lector culto infiera que para mí la moral es un producto de la subjetividad de los individuos.

Es cierto que yo no me pronuncio claramente ni a favor ni en contra del cognitivismo moral, pero soy cognitivista. (Pragmáticamente me resulta difícil no serlo.) Sólo que, ¿cómo investigar las verdades morales o éticas? Para los intuicionistas está claro cómo hacerlo, pero yo carezco de intuiciones. En cualquier caso pienso que hay dos escalas axiológicas diferentes: la ética y la nomológica. La primera: (1) su fin es la perfección personal (no sólo una vida moralmente buena sino una personalidad, un modo de ser moralmente loable); (2) con relación a ella el criterio de que disponemos es nuestra propia conciencia moral; (3) posee un ámbito muy amplio, que no sólo abarca las conductas que afectan al bien público, sino igualmente las de la vida privada; y (4) exige, para considerar moralmente valioso un comportamiento, que se haya efectuado por motivos moralmente buenos.

¿Existe una moral interna del Derecho? ¡Sea! ¿En qué difiere de lo que yo llamo «Derecho Natural»? Si se me concede que esa moral interna del Derecho tiene su propia escala axiológica, separada de la moral subjetiva (o sea la caracterizada por los cuatro rasgos que le he atribuido), estaría dispuesto a aceptar esa denominación. Y aun eso no incondicionalmente, sino siempre y cuando a esa moral interna se le asigne la cualidad que yo atribuyo del Derecho Natural, o sea: poseer vigencia jurídica —quiéralo el legislador o no- y, por consiguiente, potencial 
exequibilidad cuando las condiciones sean propicias. Esa vigencia se impone al legislador y al poder constituyente. Además, el Derecho Natural es eterno, aunque surta efectos diversos según van variando las circunstancias histórico-sociales.

Persiste el problema de si en la realidad hay una o dos escalas axiológicas. A favor de mi dualismo aduzco los frecuentes conflictos que, creo, todos hemos experimentado. No es menester adherirse a la visión de Maquiavelo para reconocer que los imperativos del orden jurídico muchas veces colisionan con la moral. La posibilidad de un continuum que establezca una transición de una escala a la otra la dejo como una cuestión abierta. (Soy, sí, continuista, más no creo que entre cualesquiera dos realidades haya continuidad, ni siquiera si se dan solapamientos y similitudes entre ellas.)

Antes de concluir este apartado me gustaría abordar, someramente, dos cuestiones un poco incidentales del comentario de M. Atienza. El primero es su intento de salvar al menos alguno de los distingos de Hohfeld aduciendo un ejemplo interesante y no banal: el pugilato. No sé si le ha pasado al lector, pero a mí, cuando estudié el art. 20.7 del Código Penal de 1995, me surgieron muchos cuestionamientos tanto sobre su alcance cuanto sobre su posible solapamiento con otras eximentes: "cumplimiento de un deber o ejercicio legítimo de un deber, oficio o cargo». Los manuales traían - creo que todos- el ejemplo del pugilato (u otros deportes de lucha). Atienza nos dice que a un boxeador le es lícito golpear a su adversario sin que éste tenga deber de soportar los golpes. (Es un caso totalmente distinto del de deportes de competición, porque el primer ciclista que cruza la línea de meta no impide nada a sus rivales.) Reconozco que da mucho hilo ese tema. ¿Es una causa de exculpación o de justificación? Si es de justificación, ¿cómo así es lícito impedir por la fuerza una conducta también lícita? Me inclino a pensar que, si bien a cada púgil le es lícito, valiéndose de sus puños, tratar de impedir el golpe del adversario, tiene, así y todo, obligación jurídica de soportar tales golpes cuando no haya logrado esquivarlos con una maniobra pugilística. En general no tenemos obligación jurídica de soportar golpes, pero quien voluntariamente se dedica a ese deporte asume con ello ciertos deberes (nos estamos refiriendo, claro, a golpes asestados dentro de las reglas del juego - y no por debajo la cintura).

Mi segunda y última cuestión incidental es el esencialismo jurídico. Atienza aduce que una concepción como la que propongo no puede reclamarse distintivamente esencialista porque también, p.ej., Kelsen creía en una esencia del Derecho, caracterizada por la normatividad y la coactividad. Así es. Está claro que mi esencialismo se refiere a la función y al contenido del Derecho (a un contenido indeclinable, aunque —dado el carácter aditivo y no sustractivo de mi jusnaturalismo- el legislador puede agregar los contenidos que tenga por conveniente). Sólo que me pregunto qué pasaría, para Kelsen, si el legislador, Superrex, edictara una ley por la cual en lo sucesivo las normas carecerán de fuerza coactiva (lo cual para Kelsen implica perder también fuerza normativa).

Cerraré mi reflexión sobre el comentario de Manuel Atienza con sus interesantes consideraciones sobre la tortura y la esclavitud. ¿Cómo es posible que yo sea tan absolutista sobre la primera -afirmando su prohibición desde el Derecho Natural, aun en el supuesto de que aplicándola pudieran salvarse vidas de muchos inocentes - mientras que, por el contrario, emito la hipótesis de que acaso la esclavitud antigua fuera compatible con el bien común, por un imperativo de eficacia económica en aquel estadio de desarrollo de las fuerzas productivas?

El dualismo jurídico que caracteriza mi enfoque y que Atienza ha analizado con insuperable claridad me lleva a sostener que la tortura puede ser jurídicamente 
lícita; lo ha sido durante milenios. A la vez, el Derecho Natural impera la total abstención de la tortura. Tenemos una antinomia jurídica. Las normas jurídicopositivas opuestas al Derecho Natural son potencialmente inexequibles, mas esa inexequibilidad requiere que concurran circunstancias social e históricamente determinadas.

Mi absolutismo en este asunto es una respuesta a la inquietud emitida por los adversarios de la ponderación (aunque mi propio enfoque de la ponderación sea como lo recuerda Atienza- diverso del de Dworkin y Alexy). Tal inquietud esgrime la posibilidad de que, si cualquier norma es ponderable, no hay líneas rojas. Evidentemente podemos fijar otras líneas rojas diferentes de la práctica de la tortura; v.g. un determinado grado de sufrimiento. Me temo que eso sería arbitrario e ilusorio, porque ni estaría justificado el salto ni disponemos de medidores vivenciales (al menos hoy por hoy). En cambio sí existe una razón para fijar la línea roja en la tortura: es lo más degradante para el ser humano, lo que todos - o casi todos- tememos más, mucho más que la muerte. Degrada al torturado y al torturador. Los priva de dignidad, si es que «dignidad» significa algo.

Admitirla por motivos de utilidad social corrompe esa misma utilidad social. Los inocentes salvados dejan de ser inocentes: salvar sus vidas ha costado rebajar la sociedad humana al rango de la diabólica. Además, sin lugar a dudas, surge el problema de la pendiente resbaladiza: se practicará si se tiene un grado $\mathrm{G}$ de certeza de que el torturado es culpable y de que torturándolo se salvarán al menos $\mathrm{M}$ número de inocentes. (Vuelvo a preguntarme en virtud de qué criterio se da un tajazo en $G$ y en $M$.) $Y$ luego se pasa a un grado $G^{\prime}<G$ y a un número $M^{\prime}<M$ y así sucesivamente. Todo eso me resulta tan espeluznante, tan destructor de lo que entendemos por «bien común», que deduzco que lo único racional es una proscripción absoluta, sin excepción alguna.

Asimismo hay que sopesar las consecuencias indirectas de practicar la tortura. Dejemos de lado los demás problemas jurídicos que rodean al presidio de sospechosos de Guantánamo. Al margen de otras graves tachas jurídicas de tales encarcelamientos, ¿cuáles han sido los resultados de practicar la tortura en ese antro y en otros gestionados por agencias gubernamentales del Occidente -o por sus subrogados y delegatarios de países vasallos? Los efectos han sido: la exacerbación del odio, la llamarada del fanatismo y la infamia, no sólo de los gobiernos perpetradores y sus aliados, sino de los sistemas político-jurídicos y hasta de las poblaciones que, con su voto, han llevado al poder a esos gobernantes y legisladores. Los atentados terroristas se han aureolado así de una espuria legitimidad. Si es que alguna vida se ha salvado (lo cual está por probar), muchísimas, a cambio, han venido sacrificadas - vidas de quienes no tenían arte ni parte en tales enfrentamientos. Ahora bien, uno de los axiomas de la lógica nomológica (recapitulados por Atienza) establece que una conducta es lícita sólo en tanto en cuanto también lo son sus consecuencias causales.

Lo que dije sobre la esclavitud antigua fue a título de hipótesis. Pero entonces, objeta Atienza, ¿estaba injustificada la rebelión de Espartaco? Podría parecer que sí: por el principio de no impedimento, en la medida en que sea lícita una conducta A (la esclavitud en este caso), estará prohibido impedir A por la fuerza (sublevándose, p.ej.).

Si mi hipótesis es certera, estamos ante un caso más de antinomia jurídica. La esclavitud nunca pudo ser totalmente lícita, pues es contraria al Derecho Natural. Por ello combatirla no puede ser totalmente ilícito, ya que los insurrectos estaban amparados por el derecho natural a la libertad. Cuando tenemos una antinomia 
jurídica hay desobediencias a la ley (a una ley) que son jurídicamente lícitas. Sin llegar a casos tan extremos pienso que existen leyes absurdas, contrarias al bien común, que, en alguna medida, puede ser jurídicamente lícito desobedecer (de hecho algunas normas son prácticamente incumplibles).

$$
* * *
$$

Centrándose la aportación de Mariano Melero en el doble derecho de radicación y naturalización, hay que decir que, si bien ese tema sólo viene muy de pasada abordado en VLD (como un obiter dictum), a él se consagraba el capítulo IX de mi tesis doctoral Idea luris Logica (2015), de cuya metamorfosis proviene el libro ahora discutido. Además, Mariano percibe claramente cómo ese derecho está fortísimamente enraizado en toda mi visión de los Derechos Naturales del Hombre, la cual —aunque temáticamente defendida en un ensayo anterior (Peña, 2013) —, es un componente esencialísimo de la filosofía jurídica propuesta en VLD.

Atinadamente observa Mariano que mi visión es prekantiana, toda vez que mi jusnaturalismo sigue la estela de la tradición filosófica clásica del Derecho Natural, la anterior a Kant. ¡Cierto! Una amplia y abigarrada tradición, que abarca, desde los estoicos hasta el materialismo ateo de Diderot y el vago deísmo de los hombres de las revoluciones americana y francesa de fines del siglo XVIII. A lo cual opone Mariano la filosofía crítica de Kant, la «causalidad de la libertad», donde el orden jurídico forma parte de una razón práctica basada en postulados regulativos, no en verdades sobre la realidad, quedando ésta allende nuestra capacidad cognoscitiva.

Dudo que sea éste el lugar apropiado para discutir a fondo sobre el criticismo kantiano. Mi objeción esencial a ese planteamiento es que ignoro por qué hemos de compartir el idealismo de Kant, por qué hay que ser kantiano o poskantiano. Aún en vida del filósofo de Königsberg, varios de sus epígonos volvieron — sin reconocerlo expresamente- a un enfoque prekantiano, restaurando la metafísica como un saber — sólo que con una nueva terminología (así, Schelling y Hegel). Muchos filósofos posteriores son prekantianos: Trendelenburg, Gioberti, Rosmini, Bolzano, Brentano, N. Hartmann, Frege, B. Croce, M. Blondel, É. Gilson, Bradley, Russell, Moore y casi toda la filosofía analítica. Son los argumentos y no el orden cronológico lo que ha de determinar nuestras opciones filosóficas.

Kant (1724-1804) había venido después de Grocio, Leibniz, Wolff, William Blackstone, J.J. Burlamaqui, Montesquieu, los enciclopedistas y los pensadores de la revolución (coetáneos suyos, pero cuya producción no recibió el más mínimo impacto de la segunda Crítica kantiana, la Kritik der praktischen Vernunft, Riga, 1788). Kant es semicontemporáneo de Jeremías Bentham (1748-1832), fundador del positivismo jurídico, pero también continuador del eudemonismo de la llustración, ajeno a esa presunta revolución copernicana del criticismo kantiano. Según lo he demostrado en VLD, Kant no influyó para nada en las Declaraciones de Derechos Naturales del Hombre de 1789, 1791, 1793, 1795, 1848 (la Seconde République), las españolas de 1869 y 1873 , etc. En realidad, tampoco en la de 1948.

Los filósofos políticos que interesan a Mariano - especialmente Rawls- sí le deben mucho a Kant, pero no ha venido de su mano ningún avance en el reconocimiento jurídico-positivo de los Derechos del Hombre. En cambio, a pesar de lo que afirma Mariano, la Declaración de 1948 sí le debe mucho al jusnaturalismo, aun renunciando a contener una introducción justificativa. Según lo he indagado en (Peña, 2013), los principales redactores del texto estaban inspirados por corrientes de filosofía jurídica afines al jusnaturalismo; sólo que ni hubieran concordado en las 
formulaciones ni, sobre todo, podían esperar con ellas el relativo consenso (no unánime) que logró el articulado de la Declaración.

Aduce Mariano a favor de su visión de los Derechos Humanos — basada en consideraciones de racionalidad práctica y, principalmente, de pacto político- el hecho de que los textos jurídicamente vinculantes son actos legislativos, que carecerían de validez sin la voluntad del legislador, o sea sin la responsabilidad institucional. Sólo que los preponderantes instrumentos de Derecho internacional al respecto, los dos Pactos de 1966, no dejan de ser traslaciones al jus cogens de la Declaración de 1948, la cual reconoce esos derechos, no los crea, no los instituye, no los edicta; afirma que todos los seres humanos los tienen, no se los adjudica.

El jusnaturalismo - sin ser tan indiferente a la positivación de los derechos como lo da a entender Mariano- asevera que, con o sin positivación, los Derechos Naturales del Hombre están revestidos de vigencia jurídica, que es precisamente la tesis que rechaza Mariano.

Ahora bien, Mariano tampoco acepta el positivismo jurídico. De ahí que tenga que asumir algo, alguna exigencia suprapositiva o extrapositiva que reclame la positivación de los Derechos Humanos. La encuentra en postulados regulativos de la razón práctica (nada sorprendente en un kantiano). Sólo que, además de que algunos o muchos no creemos en esas construcciones de Kant (cuya plena inteligibilidad podría cuestionarse), ¿de qué valor jurídico están revestidos esos postulados? Si están privados de todo valor jurídico, son interpelaciones al ordenamiento normativo desde perspectivas externas y ajenas, careciendo de fuerza vinculante. Menos fuerza tienen para los descreídos, que no tenemos fe ninguna en nada de todo eso recordando, por cierto, que en el Prefacio de la segunda edición de la Kritik der reinen Vernunft, Kant se propone suprimir el saber para hacerle sitio a la fe [Ich mußte das Wißen aufheben, un zum Glauben Platz zu bekommen]. Precisó Kant en ese lugar que la moralidad era opuesta a la falta de fe, a la increencia (al descreimiento), cuya fuente sería la metafísica dogmática.

Desde luego Mariano dista de seguir en todo a Kant, de quien se distancia expresamente al afirmar: «debemos evitar seguir aquí a Kant y decir que los Derechos Humanos son las precondiciones de una agencia moral autónoma». Y es que, con todas sus peculiaridades, Kant no deja de ser un jusnaturalista, mientras que Mariano no lo es. Mas, ¿qué requerimientos o demandas o postulados de racionalidad práctica atraen, como imanes, a la positivación de los Derechos Humanos, aun careciendo de suyo de fuerza normativa? Mariano cita aquí a Joshua Cohen, quien ofrece una perspectiva o un terreno de deliberación sobre estándares que pueden exigirse a las sociedades políticas, lo cual resume como un ideal de razón pública. Ignoro por qué hay que atenerse a ese ideal. Para mí, carece de méritos $-\mathrm{y}$, todavía más, de eficacia- ese ofrecimiento de perspectiva deliberativa. En la realidad las positivaciones de Derechos Humanos se han llevado a cabo con escasa deliberación, salvo de minorías. ¿Cuántos españoles deliberaron sobre los derechos que se iban a reconocer en la vigente Constitución de 1978?

Toda la argumentación de Mariano contra el derecho de emigración e inmigración se desprende de la visión - que él abraza, siguiendo a Cohen- de que los Derechos Humanos son normas asociadas con la idea de ciudadanía, e.d. la afiliación o inclusión en una sociedad política organizada.

De ser así, efectivamente, no hay derecho de inmigración. Pero me pregunto si existe un derecho de procreación, pues los nuevos habitantes que provengan del engendramiento no habrán suscrito el pacto político, al cual se incorporarán sin 
mediar la aquiescencia de los demás socios, los demás ciudadanos. Si el pacto social contiene una cláusula autorizando a procrear, ¿por qué va a carecer de otra permitiendo acoger a extranjeros que se quieran incorporar? En cuanto al derecho de emigración, veo bastante frágil su rechazo incluso desde los supuestos rawlsianos. Si entiendo bien, lo que argumenta Rawls es que el pacto social no ha de contener una cláusula por la cual la única opción a un trato injusto sea marcharse; o sea, no ha de organizarse la sociedad de manera que, en la práctica, se constriña a un socio a salir. Mas ¿por qué ha de rehusársele el derecho de abandonar la sociedad en pos de mejores oportunidades en otros países? (En suma, un derecho viejo como el mundo, el de sustraerse al pacto social emigrando, del cual trató Platón en el Critón; v. Kirkpatrick, 2014.) Sólo encuentro - entre las citas directas o indirectas de Marianoel argumento de que se sufre mucho emigrando, al tener que cambiar de lengua, cultura, vínculos, conexiones y valores; quien esto escribe vivió 18 años de exilio, durante parte de los cuales, efectivamente, mudó de lengua en su hablar, escribir, pensar e incluso soñar, sin que aparentemente eso lo haya dejado aplanado o empobrecido; al revés, creo que me enriquecí mucho.

Dudo que sea atinado acercar mi enfoque al de los cosmopolitistas con los cuales debate Mariano, quienes «sitúa[n] la comunidad internacional en el mismo plano [que los Estados] de responsabilidad institucional de [...] protección y promoción efectivas [de los Derechos Humanos]». Dudo haberme llamado nunca "cosmopolitista», pero, en cualquier caso, abjuro de esa etiqueta. Al revés, soy estatista, westfaliano. Creo que la protección y el amparo de los Derechos Humanos está en el Estado, al cual debemos la seguridad social, los instrumentos de redistribución, los tribunales, las obras públicas, los múltiples y variados servicios públicos. Ni siquiera miro con benevolencia los entes supranacionales (desdeño fuertemente las integraciones que no se basen en una lengua y una historia política compartidas) ni albergo esperanzas sobre los organismos internacionales, que han resultado tan decepcionantes.

Sólo que el Estado-Nación tiene obligaciones, no sólo para con sus habitantes, sino también para con los demás miembros de la familia humana, sin que ésta esté constituida como entidad política (o estándolo muy mal), ya que lo que funda los derechos y los deberes de la comunidad hacia los individuos y viceversa es una preceptividad natural del bien común; un bien común que demanda la apertura, en tanto en cuanto el bien común de los habitantes circunstanciales de un territorio no puede hacerse en detrimento del bien común de la familia humana (la res Publica totius humani generis de Fray Francisco de Vitoria, O.P.)

Por eso, efectivamente, soy aperturista, como lo recuerda Mariano, sin avalar para nada instituciones transnacionales o internacionales encargadas de velar por los Derechos Humanos, cuyo balance es poco halagüeño. Cada ser humano tiene deberes y derechos erga omnes; por lo tanto, también con relación a Estados extranjeros -incluyendo el derecho de radicación y naturalización, sujeto a las posibles colisiones con otros derechos, por lo cual no es absoluto.

Omito aquí el detalle de las objeciones que me dirige Mariano en lo atinente a esos derechos, puesto que nuestras discrepancias se infieren de los desacuerdos ya examinados en los párrafos precedentes. Si sólo hay Derechos Humanos en la medida en que están normativamente positivados en el seno de una comunidad política territorialmente demarcada y únicamente para sus habitantes, entonces no puede haber ningún derecho fundamental a inmigrar.

No se olvide, empero, que one man's modus ponens is another man's modus tollens. El derecho migratorio lo han practicado y ejercido los humanos durante 
centenares de miles de años; su denegación ha empezado a raíz de la I Guerra Mundial. (Recordemos cómo, en El mundo de ayer, Stefan Zweig añora la libertad migratoria, sin necesidad de pasaportes ni visados, hasta 1914.) Una teoría que avale esa denegación me resulta, ya por eso, carente de atractivo y de verosimilitud.

Únicamente voy a agregar un obiter dictum significativo e importante. Mariano cita una sentencia de la Corte Interamericana de Derechos Humanos en la cual, además de imponer la práctica de la acción afirmativa (que yo condeno), estipula que no podrá incurrirse en discriminaciones por condición migratoria. Pues bien, justamente, en el capítulo IX de Idea luris Logica abogo por esa discriminación, inevitable contrapartida de la libertad inmigratoria. Quienes voluntariamente vengan, ¡que lo hagan! No se les cierra el paso. Tendrán que ponerse en la cola y, tras pasar un plurienio de noviciado, cumplir determinados requisitos para naturalizarse, adquiriendo así todos los derechos (mejor dicho, habilitándose así para exigirlos frente a la nueva comunidad a la que optan libremente por incorporarse).

Está claro que un cambio jurídico como el reconocimiento de la libertad migratoria ha de llevar aparejada una rectificación de las tablas de derechos, que han sido diseñadas de suerte que tan sólo resulten viables bajo la condición de rehusar a los extranjeros el derecho a inmigrar.

Resultaríame arduo mejorar la sucinta exposición de mis ideas que hace Alfonso García Figueroa, cuyos elogios desbordan mis méritos. Hay dos puntos en los cuales son acertadas las críticas que me dirige Alfonso.

En primer lugar, lo atinente a la presunta tesis «Hume-Moore» de la indeducibilidad de lo normativo (o lo deóntico, o lo axiológico) a partir de premisas fácticas. En verdad esa tesis es un invento, una amalgama esgrimida en las polémicas para desacreditar a cuantos incurran en la dizque falacia naturalista. Sin investigar en qué medida fuera genuinamente atribuible a esos dos filósofos británicos la tesis que vulgarmente se les adscribe, yo me he limitado a ubicarme en el campo de quienes la rechazan; un vastísimo campo, en el cual me hallo en la grata compañía de toda la philosophia perennis (ens et bonum convertuntur), Leibniz, los racionalistas de la Ilustración, Hegel, N. Hartmann y, más cerca de nosotros, Searle -lo cual ya es suficiente. Pero es que, como certeramente lo señala Alfonso, Moore no abrazó la tesis que se le atribuye. Mi reciente relectura de las obras de Hume me ha convencido de que tampoco el gran pensador escocés sostuvo lo que se le suele asignar en este particular. Cuando escribí VLD no ignoraba yo las lecturas revisionistas de esos autores y el consiguiente descrédito, entre los eruditos anglosajones, de la existencia de la tesis de marras. No obstante, mi propósito era tan sólo el de defender mi propio enfoque de metafísica jurídica, el cual, en pos de la tradición racionalista, vincula el deber-ser al ser.

También es, sin duda, acertada la crítica que me dirige Alfonso por mi sumario tratamiento de Alexy, con cuya obra (que siempre me ha producido enorme respeto) disto de estar, ni remotamente, tan familiarizado como lo está Alfonso. Por las otras citas que aporta (de textos del profesor alemán que no he leído), resulta que Alexy y yo hemos caminado en un sentido bastante convergente, al menos en algunas cuestiones fundamentales de filosofía jurídica. Lo cual me congratula, pues las rarezas de mi propuesta (que Alfonso se deleita en enumerar) no dejan de producirme algún desasosiego, en tanto en cuanto podrían ser indicios de extravagancia. Claro que tales convergencias se circunscriben a algunas cuestiones. La metafísica jurídica de VLD dudo que sea del agrado del catedrático de Kiel. 
El comentario de Alfonso, en su conjunto, tiene puntos de coincidencia con otros recogidos en este Book Forum, la mayoría de los cuales cuestionan mi radical separación entre Derecho y moral, lo cual podría darle al lector la equivocada impresión de que a mi propuesta se enfrentan, más que nada, los jusmoralistas (cuantos tratan de colocar pasarelas entre ética y Derecho), como si la mayor oposición no viniera de los positivistas puros, aquellos que, si bien coinciden conmigo en esa separación, rechazan la existencia de normas jurídicas no promulgadas.

Con relación a la ética, Alfonso tiene «la impresión de que la moral a la que alude Lorenzo Peña es una moral esclarecida, ilustrada y pura en que no hay interferencia posible de la moral social». Si he dado esa impresión, es que no me he expresado correctamente. Mi concepto de «moral» viene, a grandes rasgos, dilucidado por varias notas, agrupadas en un racimo que, lejos de formar un conjunto de condiciones necesarias y suficientes, se limita a bosquejar un contorno difuso y elástico. En esa caracterización, desprovista de pretensiones de exactitud, no se presupone ni la conexión de la moral individual con la social ni su desconexión. Sea como fuere, algo en lo que insisto - y se ve también en mi respuesta a la mayoría de mis gentiles interlocutores en este Forum - es la vinculación entre conciencia y deber moral. Qué factores estén detrás o delante de esa conciencia no es tema que yo estudie.

Si he observado dos puntos de la crítica de Alfonso en los cuales le doy la razón, subsisten, empero, tres divergencias entre nuestros respectivos enfoques. La primera es que, según lo entiende él, el Derecho es un conjunto de actos de habla regulativos regidos por una pretensión de corrección, actos de habla que forman parte de juegos de lenguaje profundamente humanos. Esa visión me parece claramente inspirada en la pragmática transcendental de Apel y en la filosofía lingüística oxoniense originada por el Wittgenstein tardío. Desde luego ese punto de vista es opuesto al que yo defiendo, según el cual el Derecho está constituido por normas, e.d. por situaciones jurídicas (generales), siendo una situación jurídica la afectación de un estado de cosas por una cualidad normativa. Algunas situaciones jurídicas resultan de actos de habla (como lo recalco en el capítulo VIII de VLD), a saber: prolaciones edictivas; otras, no. Cae fuera de los límites de este intercambio adentrarme en las razones a favor de mi propia propuesta y en contra de la concepción lingüística. Bastante me extiendo sobre eso, no ya a lo largo de los sucesivos capítulos de VLD, sino igualmente en una serie de ensayos de los últimos lustros.

Esa discrepancia está en la base de otra que al lector le resultará muy saliente: nuestro desacuerdo sobre el principio de permisión, PP, o sea aquel que, de la nodeducibilidad, en un sistema normativo, de la prohibición de una conducta, nos faculta a inferir la licitud de tal conducta en ese sistema. Alfonso se adhiere a la tesis de Alchourrón y Bulygin, por mí criticada en el capítulo VIII de VLD, tesis que introduce un distingo entre permisos débiles y fuertes. Según lo enuncia Alfonso, el PP significaría -en la versión no tautológica, que es la que yo defiendo-que lo no prohibido por norma alguna del sistema estaría, explícita o implícitamente, autorizado por una norma del sistema. Afirma Alfonso que no es así, que no tiene por qué ser así. Sólo será así —nos dice— en aquellos sistemas que hayan incorporado ese principio, siendo lógicamente posible un sistema normativo sin PP.

Ahora bien, en mi tratamiento PP es una regla de inferencia primitiva de la lógica nomológica -aplicable a cualquier sistema normativo. Su ausencia denota que el conglomerado de prescripciones que se esté considerando no es un sistema normativo. ¿Estoy equivocando al postular esa regla de inferencia y al ver en ella un rasgo esencial de la sistematicidad normativa? Es posible; no basta, empero, para 
refutarme constatar la concebibilidad de conjuntos de normas sin PP. Y es que, para cualquier axioma lógico, para cualquier regla de inferencia lógica, son concebibles conjuntos exentos de ese axioma o de esa regla de inferencia. Así, ¿refutaron Heyting y Brouwer el principio de tercio excluso, «A o no-A»? Ciertamente diseñaron la lógica intuicionista sin ese principio; tal lógica funciona, sólo que es más débil que la lógica clásica; con el intuicionismo perdemos muchas deducciones interesantes en matemáticas y en el discurso corriente. Hay lógicas conexivistas donde no se acepta el principio de simplificación alética, «Si $A \& B$, entonces $A$ ». Hay incluso lógicas sin principio de identidad, " $A=A »$-esgrimidas por algunos teóricos de la física como modo de afrontar ciertas paradojas de algunas partículas elementales. En realidad, no hay ni un solo axioma, ni una sola regla de inferencia comunes a todos los sistemas lógicos.

Los axiomas y las reglas de inferencia de la lógica deóntica se postulan por alguna razón. Yo brindo en mi libro una razón: son aquellos que permiten hacer razonamientos que, vinculando hechos y situaciones normativas, sirvan al fin de la sociedad. Los descubrimos por abducción. Entre ellos figura el PP. Alfonso acepta que tal principio es una exigencia pragmático-transcendental del Derecho y que tiene vigencia en todos los modernos ordenamientos jurídicos. No sólo eso, sino que, además, Alfonso reconoce que «por si fuera poco, el PP habría formado parte de los presupuestos que los juristas han aceptado secularmente». Me hace dudar el uso del modo potencial; no sé si su frase ha de leerse afirmativamente («formó parte») o adscriptivamente («según Lorenzo Peña, formó parte»). Pero en VLD aporto datos al respecto. Justamente por eso los adeptos del distingo inventado por Alchourrón y Bulygin lo ven como una novedad, que choca con cuanto había sostenido siempre la doctrina - positivista o no- (y que han seguido sosteniendo hoy positivistas como Raz). Siendo así, parece que siempre se interpretaron los sistemas normativos de tal manera que - aun sin enunciarlo con las palabras de hoy - se sobrentendiera la vigencia del PP. Luego su validez no es ninguna novedad de los sistemas normativos modernos.

Claro que, si el Derecho fuera un mero juego del lenguaje, un conglomerado de actos de habla, desligado de su función al servicio de la consecución de los fines de la sociedad, entonces ¿por qué no? Habría, o podría haber, juegos con cualesquiera axiomas o reglas de inferencia caprichosamente elegidos e incluso sacados al azar. Si una norma no es una situación jurídica, sino un acto de habla, entonces de la ausencia de actos de habla que entrañen cierta conclusión no se seguirá la existencia de un acto de habla que entrañe la negación de esa conclusión. La lógica nomológica propuesta en VLD no es una lógica diseñada para conjuntos de actos de habla, sino una lógica de las situaciones jurídicas.

La tercera y última discrepancia concierne al bien común. Alfonso cuestiona la utilidad del axioma del bien común dada la elasticidad que yo atribuyo a ese concepto y su variable modulabilidad en diversas circunstancias histórico-sociales, lo cual le hace sospechar que caigo en un «vaciamiento de su contenido». Dudo que sea así. El mismo cuestionamiento podría aplicarse a otras nociones afines, como «utilidad social», «interés general», «bienestar» y «felicidad». He precisado algunas veces que el bien común puede cifrarse en la cantidad y calidad de vida, colectiva y distributivamente (social e individual). A los más puntillosos tampoco eso los convencerá, ya que no dejan de ser elásticas las nociones de vida, calidad, cantidad, socialidad e individualidad. Los astrofísicos que especulan sobre la posibilidad de vida en planetas de otros sistemas estelares tienen muchas dudas sobre qué es aquello cuya existencia o inexistencia se plantea, porque no hay una definición precisa y concluyente de «vida». 
Hay una réplica pragmática al cuestionamiento de la utilidad de la noción de bien común en virtud de su indeterminación y elasticidad: tal noción viene, simultáneamente, rechazada por quienes ven en ella un peligro para el individualismo, un principio colectivista incompatible con una sociedad liberal. Espero haber argumentado en VLD lo suficiente para mostrar que el principio del bien común ni es vacuo ni tampoco es necesariamente antagónico con el liberalismo — siempre que sea un liberalismo respetuoso de los fines esenciales de la sociedad.

Certera es la reconstrucción que hace Marcelo Vásconez de mi enfoque sobre la dicotomía entre ética (o moral) y Derecho, que gira en torno a la separación entre ética y Derecho Natural. Ha logrado formular mi planteamiento en términos más claros y compactos que los que se hallan en mis propios escritos, siendo iluminadores su exploración de mi itinerario intelectual y su diagnóstico sobre mi pirronismo ético.

Como lo expresa Marcelo, siempre se ubica en el campo de la filosofía jurídica mi discusión de la ética (salvo en escritos puntuales y ya un poco añejos). Significa eso que, en mi producción intelectual, rarísimas veces he abordado una investigación filosófica autónoma sobre la ética; si, en estos últimos años, he desarrollado varias reflexiones sobre temas morales o metaéticos, ha sido únicamente en el sentido y con el propósito que capta Marcelo, como objeciones al jusmoralismo. Vienen perfilados en el texto de Marcelo los motivos intelectuales de esa autolimitación.

Estando de acuerdo con Marcelo en la mayoría de sus consideraciones, voy a ceñir mi respuesta a dos asuntos que me suscitan dudas en su trabajo.

El primero es la propuesta de una esencia objetiva de la ética que vendría, en parte, suministrada por los axiomas de una lógica deóntica correcta, en paralelo a cómo los axiomas de la lógica nomológica constituyen el núcleo del Derecho Natural. Estriba, a mi entender, la diferencia en que, en la lógica nomológica, tenemos el axioma central, la obligación de que se realice el bien común. Un axioma material, no formal. (Los demás axiomas tampoco son formales, pero su materialidad resulta menos obvia.) ¿Qué axioma o axiomas de la lógica deóntica jugarán ese papel en ética? ¿El de que es moralmente preceptivo hacer el bien y abstenerse del mal (principio de sindéresis de la tradición aristotélico-escolástica)? Se le ha reprochado su presunta vaguedad al concepto de bien común, pero ¿no nos brinda, al menos, algunas pistas hermenéuticas el adjetivo «común»? Pistas de las cuales está ayuno el principio de sindéresis.

Alternativamente podríamos buscar un catálogo axiológico, en la línea de $\mathrm{N}$. Hartmann y M. Scheler, junto con unas reglas de prelación. Percátase Marcelo de que ésa sería mi preferencia, si es que osara dedicarme a proponer una ética. Es más: en la contrafáctica hipótesis de que yo renunciara a mi tesis de la separación entre ética y Derecho Natural - 0 , al menos, la atenuara-, seguiría verosímilmente los pasos del maestro Eduardo García Máynez, un gran estudioso de la axiología hartmanniana, que supo aplicar a su filosofía jurídica. Sin embargo, como lo apunta Marcelo, albergo dudas acerca de la factibilidad de ese proyecto $-\mathrm{y}$, sobre todo, acerca de su justificación epistémica. Podemos construir una ética con esos instrumentos, pero ¿cómo probar que es verdadera? Sin demostrar que lo es, ¿cómo exigir a los demás ajustar sus pensamientos y sus hechos a esa ética, en lugar de otra? No se me conteste que quien elabora una ética no impone nada de los demás, sólo propone. Sí, evidentemente, propone; y no se dirige al poder público exhortando a que éste use la coerción legítima al servicio de la normativa ética así propuesta. Pero, sin lugar a 
dudas, quien enuncia una ética se siente, explícita o implícitamente, (moralmente) autorizado a reprochar conductas que la conculquen y a loar aquellas que la cumplan.

En el campo jurídico hay un argumento transcendental a favor de la lógica nomológica, incluido el axioma del bien común. Quienes promuevan ordenamientos normativos que se aparten de esos principios destruyen o socavan su propia empresa. (Razono según el modelo de Lon Fuller con relación a la hipótesis del caprichoso legislador Rex.) En la teoría ética, el proyecto más ambicioso de racionalismo moral es -en mi opinión- el de Alan Gewirth. Reconociendo su atractivo, confieso mi perplejidad al respecto. Es una temática fascinante, pero no es la mía. Cierto que he aspirado a ofrecer un nuevo sistema filosófico, pero no sin lagunas. (¿Qué sistema más acabado y exhaustivo que el de Hegel? Aun así, el filósofo del idealismo absoluto no publicó ningún tratado de ética y sí uno de filosofía jurídica. Mis pretensiones son mucho más modestas que las de Hegel.)

No se les planteaba a N. Hartmann ni a M. Scheler el problema de la prueba de verdad de sus estimaciones éticas, porque apelaban a la intuición emocional de los valores. Yo he reiterado mi total escepticismo sobre cualquier tipo de intuición. Mi experiencia vivencial no me ha permitido nunca intuir nada. Conque quienes disfruten de ese privilegio epistémico de poder intuir, si son filósofos, parece que algo deberían hacer para que los demás creamos en la verdad de sus intuiciones.

En la elaboración de la lógica nomológica el principio del bien común no sirve sólo como axioma central del sistema, sino también como pauta heurística para la abducción de todos los axiomas y todas las reglas de inferencia. Tomamos los argumentos de la praxis jurídica; los filtramos por un cedazo, que es el de quedarnos sólo con aquellos cuya utilización sirva al bien común. Mientras no tengamos unos axiomas materiales esenciales para una lógica deóntico-ética, carecemos de una pauta heurística general.

Como lo ha percibido Marcelo, en uno de mis más recientes ensayos he rectificado, en parte, mi tesis de que la ética busca el perfeccionamiento personal. Cito lo que él dice: «puesto a buscar una [función de la ética], encuentra que es el mejoramiento de las relaciones entre los miembros de la sociedad, lo cual de manera indirecta contribuye así a la armonización del tejido social».

Tal vez esa somera indicación de pasada podría darnos una pauta. Si el Derecho es la normativa de la vida pública, o sea de la sociedad (de la Sociedad con mayúsculas, del cuerpo político), quizá la ética es la normativa de la vida privada, de las microsociedades - 0 , más correctamente, de la vida personal e interpersonal-: de las familias, de las agrupaciones de amigos o cualesquiera otras, sin fuerza coercitiva, pero con sanción reprobatoria; o, mejor dicho: es aquella normativa de las microsociedades que no apela a la normativa pública. Esa normativa consuetudinaria, las costumbres, constituiría la materia prima, a partir de la cual, por abducción, podríamos inferir principios fundamentales requeridos para que, en esas múltiples células del tejido social, reinen armónicas relaciones. No se trataría de tomar, sin más, los juicios de alabanza o vituperio que vienen asumidos por la gente en una particular sociedad, porque, si la ética verdadera se halla reverberada en la moral social, también suele estar en ella adulterada y alienada. No hay que olvidar que también existe un Derecho interno de las colectividades —las asociaciones, las múltiples figuras societarias y organizativas privadas; precisamente por eso $-y$ a fin de deslindar los campos- entiendo el campo de la ética, no como el de las relaciones privadas en general, sino, en particular, como el de los vínculos interpersonales. 
Paso al segundo problema. Marcelo es muy cuidadoso y preciso en citar sus fuentes sobre el utilitarismo, en particular, y el consecuencialismo, en general; pero en su propia exposición surge una dificultad. Aceptemos que es verdad lo que voy a llamar "el principio evaluativo del consecuencialismo», PEC, a saber: que la evaluación moral de las conductas ha de hacerse exclusivamente por sus consecuencias causales. (Personalmente $-\mathrm{y}$ a pesar de las citas aducidas por Marcelo- dudo que el PEC haya sido asumido por Sidgwick, Bentham, J.S. Mill, J.J.C. Smart, Peter Singer y tantos otros consecuencialistas, al menos bajo una enunciación tan contundente. Algunas de las citas que parecen corroborar el PEC vienen de adversarios del consecuencialismo — sobre todo adeptos de la mal llamada «ética deontológica», un intencionalismo de raigambre kantiana.)

Marcelo mismo puntualiza que «hay un sentido en el que es adecuado enunciar que el consecuencialismo sea subjetivo», no siendo irrelevantes «las consecuencias que un sujeto pueda prever o racionalmente esperar», si bien estima - siguiendo a Sinnot-Armstrong - que eso no hace «depender el criterio de obligatoriedad de algún contenido en la mente del sujeto». ¿No? ¡Vamos a ver! O bien son moralmente relevantes las previsiones y las expectativas del agente o no lo son. Si lo son, ¿cómo no lo van a ser para fijar el criterio de obligatoriedad en función de contenidos en la mente del sujeto? Es justamente esa relevancia de la previsibilidad de los resultados lo que, a mi juicio, zarandea el PEC.

Cabe causar un daño por caso fortuito, por imprudencia, por indiferencia o adrede. Si el agente previó el daño, lo ha hecho adrede (dolo directo). Si le traía sin cuidado que se produjera o no, ha actuado con indiferencia (dolo eventual). Si podía preverlo, pero no prestó atención, ha obrado imprudentemente. Si era imposible preverlo o evitarlo, se ha tratado de caso fortuito. Son distingos del Derecho penal, pertinentes para la ética.

Siendo así, me resulta inverosímil que el consecuencialismo esté prescindiendo de las intenciones, decretando moralmente irrelevantes las previsiones del agente; y, por lo tanto, sus intenciones. Tampoco el Derecho prescinde de ellas. Sólo que el Derecho únicamente las toma en cuenta en la medida en que, en las conductas, se ha violado la ley. La valoración moral no puede, en cambio, circunscribirse a los casos en que se haya transgredido la norma ética, sino que ha de abarcar también aquellos en que se ha observado dicha norma.

Una vez que el consecuencialista modula el PEC introduciendo la previsibilidad de los resultados — bajo una enunciación que requiere precisarse-, surge automáticamente la pregunta de si, para él, la valoración moral ha de centrarse en las consecuencias reales o en las previstas (dejando de lado la hipótesis de un problemático adscribir la misma importancia a las unas y las otras). Si elige la primera opción, debemos cuestionar (como lo han hecho sus adversarios) que se trate, en realidad, de una teoría ética o moral, porque no serviría como regla de conducta; sólo se aplicaría en tercera persona, como criterio externo de valoración (una dicotomía que Marcelo recoge en su exposición). Si se elige la segunda opción, creo que, entonces, reincidimos -en este punto al menos- en lo que yo me he esforzado por argumentar en VLD: la ética atiende preferentemente a la intención de los agentes (aunque, a su vez, se calibre ésta con el criterio de la previsión o previsibilidad de los resultados, descontándose la «buena intención» de quien obra a ciegas, pase lo que pase —o sea de quien siga la máxima «¡Haz el bien y no mires a quién!» o alguna similar); y su campo es el de toda la conducta humana. Por el contrario el Derecho tiene un campo más limitado, escudriñando la intención únicamente en el caso de actuaciones antijurídicas. 
Insisto en que el problema aquí no estriba en saber si «el utilitarismo [está] equivocado», sino en que una "teoría [que] mantiene que las intenciones son irrelevantes para valorar los actos» no puede ser una teoría ética ni moral (ni siquiera jurídicamente admisible - como no sea en ordenamientos arcaicos que el progreso de las ideas normativas superó hace miles de años).

Dudo que tenga éxito la objeción final que me dirige Marcelo: «si [...] el axioma del bien común [...] se justifica[...] por el consecuencialismo, y ésta es considerada típicamente como una doctrina de la ética, resultaría que el Derecho Natural dependería fundamentalmente de la ética». La respuesta la ha previsto él mismo: «acudir una vez más al dualismo, distinguiendo, en esta ocasión, dos tipos de consecuencialismo, uno ético y otro jurídico». A lo cual replica: «llevado el dualismo hasta sus extremos, quizás resulta un poco desmesurado».

No veo en qué o por qué es desmesurado. Ya hemos visto que, si el consecuencialismo ético quiere ser una teoría moral, ha de tomar en cuenta las intenciones; también lo hace el Derecho, pero más limitadamente. $Y$ las consecuencias relevantes no son las mismas. En el Derecho sólo se tienen en cuenta consecuencias atinentes al bien común, a la cantidad y calidad de vida, colectiva e individual, de una sociedad. No me incumbe discurrir aquí sobre cuándo son éticamente relevantes las consecuencias de nuestros actos, pero juzgo que forman un ámbito mucho menos circunscrito ( $\mathrm{y}$, verosímilmente, más orientado a las relaciones interpersonales).

Marcelo nos ha ofrecido un brillante análisis sobre la teoría ética, pero no ha conseguido aportar auxilio alguno al jusmoralismo. Lo último que querría éste sería reputar relevante para el Derecho una presunta ética como el consecuencialismo según Sinnot-Armstrong, para el cual el criterio de obligatoriedad no depende en absoluto de ningún contenido en la mente del sujeto (una indiferencia a las intenciones mucho más radical que la del propio ordenamiento jurídico).

Las objeciones de Marcelo han suscitado en mí una inquietud sobre la posibilidad de una investigación ética objetiva (reflejada unos párrafos más atrás), sin quebrantar, empero, mi convicción de que Derecho y moral son normativas disjuntas e independientes entre sí.

Es una suerte poder contar con el prolijo y cuidadoso texto de José Juan Moreso, quien tiene la amabilidad de recordar facetas de mi previa trayectoria, en los campos de la lógica y la metafísica, vinculándolas a la obra ahora discutida, VLD, para lo cual despliega su acreditado dominio de la filosofía de la lógica y del lenguaje, dos disciplinas que suelen caer fuera del ámbito de competencia de los filósofos del Derecho.

Repróchame el profesor catalán mi tesis de la suficiencia de la edicción legislativa para hacer existente una obligación (o una prohibición o un permiso). Cita mi aserto: "Aquello que hace verdadera la prolación deóntica edictiva es la propia existencia de esa misma prolación, la cual es así autofundante». Llamemos a mi afirmación «Principio de Omnipotencia del Legislador», POL. Moreso objeta a POL:

Siendo así, me temo, y dado que cualquier oración puede ser proferida por una autoridad, la posición de Peña, de tomarnos en serio tal afirmación, hace de su lógica, no una lógica paraconsistente ni dialéctica, sino una lógica trivial, dado que todas las normas (también las contradictorias entre sí) emitidas por una autoridad son verdaderas, que es la tesis del trivialismo. 
El párrafo recién citado del comentario de Moreso lo denominaré $\boldsymbol{A T}$ (acusación de trivialismo). AT se presta a dos lecturas:

- ( $1^{a}$ lectura) POL entraña que todas las fórmulas sintácticamente bien formadas, «A», sean tales que «A» resulte afirmado como verdad. Tal entrañamiento será una trivialidad general.

- ( $2^{\mathrm{a}}$ lectura) POL entraña que todas las fórmulas sintácticamente bien formadas, «A», sean tales que «oA» resulte verdadero en el sistema jurídico de referencia. Tal entrañamiento será una trivialidad deóntica.

Con relación a la $1^{\text {a }}$ lectura, hay que distinguir entre proferir una oración y proferirla edictivamente -o sea, hacer con ella un acto performativo de índole edictiva. Para proferir edictivamente una oración son menester dos requisitos esenciales:

$\left(1^{\circ}\right)$ Que la oración así proferida sea deóntica, e.d. que la oración entera caiga bajo el alcance de un operador deóntico — sea el de obligación, sea el de licitud, sea el de prohibición. (Son también deónticas aquellas oraciones que resulten de prefijar a una fórmula deóntica un cuantificador universal.)

$\left(2^{\circ}\right)$ Que el proferente esté en condiciones pragmáticamente idóneas para, al enunciar esa oración deóntica, hacer un acto de habla que sea una prolación edictiva; o sea: que esté revestido de autoridad suficiente y profiera la oración según determinadas formalidades socialmente convenidas (reglas hartianas de reconocimiento). (Hace falta, pues, un entorno de elocución adecuado.)

El primer requisito refuta la $1^{\text {a }}$ lectura de AT, puesto que, por mucho que el legislador profiera un enunciado no deóntico, esa prolación no es edictiva (ni, por consiguiente, cae en el ámbito de aplicación de POL).

Así lo confirma, acertadamente, el Consejo Constitucional francés, en fecha de 21 de abril de 2005, declarando contraria a la Constitución una disposición legislativa "desprovista de alcance normativo», fundándose en el art. 6 de la Declaración de los derechos del hombre de 1789 y en otras normas de valor constitucional relativas al objeto de la ley. (Eso anula pseudoleyes como la del 29 de enero de 2001, cuyo art. 1 reza: «Francia reconoce públicamente el genocidio armenio de 1915».) Al hacer ese pronunciamiento el alto tribunal francés lleva razón frente a Kelsen, para quien «una ley adoptada de manera perfectamente constitucional» puede «tener un contenido que no representa una norma de ningún tipo», «sino que, p.ej., expresa una teoría religiosa o política» (Kelsen, 1972, p. 71).

Refutada así la $1^{\text {a }}$ lectura, sólo queda, como posible interpretación de AT, la $2^{\mathrm{a}}$ lectura. ¿Acarrea POL la trivialidad deóntica del sistema jurídico? ¡No, en absoluto! La acarrearía si la lógica deóntica adoptada fuera una LDE (lógica deóntica estándar), como las de Alchourrón y Bulygin y aquellas en que ha trabajado el propio Moreso. En esas lógicas las consecuencias lógicas de contenidos obligatorios son también obligatorias (regla de cierre lógico). Conque, si el legislador edicta "OA» y —quizá en otra ocasión- "OᄀA», entonces, al tener esas lógicas como su cálculo sentencial subyacente el clásico —donde vale la regla de Cornubia (según la cual de un par de premisas, una de ellas negación de la otra, se deduce cualquier conclusión)—, en esas lógicas estándar se seguirá «oB», para cualquier «B»; será un sistema afectado por trivialidad deóntica. 
Mas, como lo acabo de decir, la lógica nomológica propuesta en VLD no acepta la regla de cierre lógico, o sea: de «oA» y $-A \rightarrow B$ no se deduce «oB». En la lógica nomológica las consecuencias lógicas de contenidos obligatorios pueden y suelen no ser obligatorias.

Ciertamente la lógica nomológica posee sus propios axiomas y reglas de inferencia —estudiados en el capítulo II de VLD y recapitulados en la p. 195. Así pues, también con la lógica nomológica comprométese el legislador, con sus promulgamientos explícitos, a la vigencia de normas derivadas que él no ha promulgado (ni quizá previsto). Sin embargo, el potencial deductivo de la lógica nomológica, totalmente diverso del de la LDE, resulta — habida cuenta de todomuchísimo más débil. Para nuestro propósito lo esencial es que con la lógica nomológica jamás se produce ninguna explosión inferencial; quedan muy acotadas las consecuencias lógico-nomológicas.

El ordenamiento jurídico puede y suele contener antinomias, «oA» y «O A» (siendo « » la negación débil, el mero «no») e incluso puede contener antinomias fuertes, «oA» $y$ «OᄀA» — siendo «า» la negación fuerte, el «no... en absoluto». Nótese que en la lógica nomológica «O A» implica « OA», pero, en cambio, de «0 $\neg$ A» no se sigue « $\neg \mathrm{A} »$. O sea, el principio de subalternación deóntica no vale para la negación fuerte. Por otro lado el cálculo sentencial subyacente es la lógica gradualista (una lógica paraconsistente para la negación débil, « », o sea: para esa negación no vale la regla de Cornubia). (Si el principio de subalternación deóntica valiera para la negación fuerte, un sistema con antinomias fuertes acarrearía la trivialidad general.)

De ahí que, según mi propuesta nomológica, para que, en un ordenamiento jurídico, se produzca una trivialidad deóntica - e.d. para que sean verdaderos todos los asertos del tipo «oA»- será menester que el legislador haya ido edictándolos todos, uno por uno. Sería un legislador no humano, claro está; nótese, en efecto, el distingo entre: $\left(1^{\circ}\right)$ que cualquier enunciado deóntico pueda venir edictado por el legislador; y $\left(2^{\circ}\right)$ que el legislador pueda edictar todos los enunciados deónticos. Lo segundo cae fuera del ámbito de las posibilidades humanas.

Afortunadamente mi propuesta en VLD pone una barrera a la desmesura legislativa que causaría un estrafalario legislador al que se le ocurriera ponerse a amontonar preceptos y más preceptos sin ton ni son; consiste esa barrera en el principio jurídico-natural de que, cuando un cúmulo de normas ya no sirve, ni siquiera laxamente, para regular la sociedad en aras del bien común, deja de ser un ordenamiento jurídico, perdiendo así el legislador la aptitud para edictar normas (pues, en verdad, cesa de ser legislador).

Eso marca uno de los dos límites a POL. El segundo límite es que hay edicciones nulas en virtud de constreñimientos de lógica nomológica. En tales casos, la edicción es jurídicamente inexistente (o, como mínimo, írrita). En mi libro detallo algunos casos. (Atienza señala que son imaginarios.)

Notemos que - a pesar de esas dos limitaciones- POL es una tesis que mi propuesta toma del positivismo jurídico, justamente por rechazar el jusnaturalismo sustractivo. Para éste último la edicción legislativa no es condición suficiente de vigencia jurídica. Para mí sí —con esas dos limitaciones. En la medida en que no sean transgredidos esos dos límites, toda prolación edictiva del legislador crea Derecho. Abrazando POL, estoy (en eso) en la línea de Kelsen (aunque restringiendo su principio de indiferencia del contenido por la exigencia de que sea un contenido deóntico y no de otro tipo). (De ahí que Atienza pueda decir, no sin fundamento, que mi propuesta es una síntesis peculiar de jusnaturalismo y positivismo.) 
También objeta Moreso a POL que no basta la prolación edictiva para que se cree una situación jurídica, sino que la misma requiere que se satisfagan ciertas condiciones. No hay desacuerdo alguno entre nosotros sobre ese punto. Lo que pasa es que, si no se dan esas condiciones, no hay tal prolación edictiva. Para que con un performativo se haga una prolación performativamente calificable, es menester que sea apropiado el contexto de elocución. Vale eso para performativos como «preguntar», "mandar», "prometer», «jurar». Y, obviamente, para «edictar». Una edicción tendrá que venir hecha por el legislador según determinadas formalidades y en determinado entorno; si no, no hay edicción.

En relación con eso, Moreso cita mi objeción a Alchourrón y Bulygin en la cual digo: «resulta problemática la mezcla, en una misma oración compuesta, de una cláusula aseverativa ( $\mathrm{y}$, por lo tanto, portadora de valor veritativo) y otra dizque prescriptiva y, a fuer de tal, carente de tal valor; no está clara la naturaleza del resultado de ese acoplamiento». Lo trae a colación del modus ponens deóntico (vide infra). Bien, pero yo no acepto que haya cláusulas prescriptivas carentes de valor veritativo. Es una tesis de Alchourrón y Bulygin, con los cuales estoy discutiendo en ese fragmento de mi obra (en el capítulo VIII). En mi propio tratamiento la oraciones deónticas son verdaderas o falsas, no habiendo entonces problema en mezclarlas con oraciones que enuncien supuestos de hecho. (Justamente así escapo al dilema de Jørgensen que menciona Moreso.)

Creo que, a este respecto, hay que despejar un equívoco. Moreso dice que, en mi tratamiento, «las normas jurídicas son performativos (jusivos los llama)». ¡Precisemos! Una norma jurídica emanada por el legislador es la fuerza ilocucionaria de un jusivo (de un performativo de edicción o promulgación). Pero hay que distinguir entre la fuerza ilocucionaria de una prolación performativa y aquello que significa esa prolación.

Para ser más exactos, aquello que sostengo es que el legislador tiene dos opciones: instituir la norma por una prolación performativa de la forma «Preceptúo que A» o instituirla por una declaración deóntica —con valor también edictivo- de que su contenido es obligatorio (o sea declarar, edictivamente, «Es obligatorio que A»). La primera opción se plasma en un acto de habla cuya fuerza ilocucionaria es el surgimiento de la obligación; sin embargo lo significado por la oración proferida en tal acto de habla no es eso, sino el hecho de que el legislador está preceptuando que A. En cambio, con la segunda opción coinciden la fuerza ilocucionaria y el significado o sea, el contenido locucionario.

Pasando ahora a otra cuestión diferente, objeta Moreso mi rechazo del principio de simplificación deóntica, o sea aquel que permite -en la LDE- inferir «oB» de «o(A\&B)». Alega que no vale uno de los muchos contraejemplos que yo aduzco en contra del mismo. No quiero discutir ese contraejemplo en particular; pero hay miles de contraejemplos. Uno de ellos es que, si Ángel, al terminar su jornada laboral, tiene que salvaguardar las operaciones del día en un disco duro externo y apagar la computadora, no por ello tiene que apagar la computadora (si no ha salvaguardado los datos). En su empresa le han marcado esa doble obligación por varios motivos: que no se pierda la huella de las operaciones $y$, a la vez, no se someta la máquina a inútil desgaste. Pero, puesto a no cumplir el primer conyunto, $A$, es mejor no cumplir tampoco el segundo conyunto, B, porque así, al día siguiente, el operario que se incorpore a las 8 de la mañana podrá proceder a la salvaguarda.

Lejos de que sea una extravagancia mía rechazar ese principio de simplificación, es un tema muy discutido en la filosofía moral analítica, que opone a los posibilistas y a los actualistas y que se suscitó en torno a (Jackson \& Pargetter, 
1986). El Profesor Procrastinador se ha comprometido a lo siguiente para el 1 de junio: leer tal libro y entregar a la revista una reseña del mismo. Supongamos que, tras haberlo ido dejando para mañana, el 31 de mayo se ve azorado y en apuros; para salvar las apariencias, improvisa una reseña y la manda. Sin haber leído el libro. ¿No hubiera sido mejor, ya que no lo ha leído, que no cumpliera la presunta obligación derivada de reseñarlo?

Moreso puede replicar que Procrastinador no está cumpliendo el segundo conyunto, enviar una reseña, pues pragmáticamente se sobreentendía que tenía que ser una reseña emanada de una previa y atenta lectura del libro. Bien, pragmáticamente es posible (tendríamos una implicatura conversacional -en la terminología de H.P. Grice), pero, en estricta lógica, su obligación era doble: leer y escribir. No sabemos si su reseña fue laudatoria, pero juzgamos verosímil que una reseña inventada sea peor que una omisión de reseñar (quizá el libro merecía una zurra). De rechazar Moreso éste y todos mis demás contraejemplos, me pregunto para qué sirve entonces el principio de simplificación, si es que en la práctica siempre vamos a sobreentender la obligación de contenido conyuntivo de tal manera que tengamos un bloque inescindible.

Antes de cerrar esta respuesta a Moreso haré una breve discusión del modus ponens deóntico, MPD, a saber: « $(\mathrm{o}(\mathrm{A} \rightarrow \mathrm{B}) \& A) \rightarrow O B »$. $O$ sea: en tanto en cuanto suceda $A$, siendo, a la vez, obligatorio que de $A$ se siga $B$, resultará obligatorio $B$. (Dicho con otras palabras: Dadas la ocurrencia de $A$ más la obligatoriedad de que $A$ implique B, es preceptivo B.)

Moreso me objeta: «No veo qué ganamos con esa maniobra, entonces mejor quedarse con la concepción puente». En la jerga lógico-deóntica la concepción puente es aquella que coloca el operador de obligación delante de la fórmula implicativa «A $\rightarrow B »$, mientras que la concepción insular lo coloca delante de la apódosis, «B». O sea, la concepción puente representa una obligación condicional o implicativa como «o $(\mathrm{A} \rightarrow \mathrm{B}) »$, al paso que la concepción insular la representa como «A $\rightarrow \mathrm{OB} »$.

Sí, efectivamente, las obligaciones condicionales o implicativas sólo son correctamente enunciadas con la concepción puente. Por tres razones.

(19) Con la concepción insular sería un hecho implicativo $-y$ no una obligaciónaquello que, al edictar un precepto, estaría enunciando el legislador. Ahora bien, un hecho implicativo no puede ser edictado. Como ya lo hemos visto párrafos atrás (a propósito de la sentencia del Conseil constitutionnel de 200504-21), un acto de habla performativo de edictar sólo tiene sentido (sólo es un acto de esa índole) cuando lo proferido es una oración deóntica, o sea una que cae bajo el alcance de un operador de obligación, prohibición o licitud, al cual generalmente viene prefijado un cuantificador universal.

$\left(2^{\mathrm{a}}\right)$ La obligación preceptuada por el legislador, enunciada correctamente con la concepción puente, da una opción a cada destinatario del precepto; sea abstenerse de A (en aquellos casos en los que está en su mano), sea realizar B. Son dos maneras alternativas de cumplir la obligación. Eso en cambio no es posible con la concepción insular.

$\left(3^{a}\right)$ Si aceptamos la concepción insular, perderemos la imprescindible diferencia entre el hecho deóntico de que sea preceptivo que, en la medida en que $A$, se realice $B$ y el hecho fáctico de que, en la medida en que se dé el estado de cosas A, sea preceptivo B. 
Ahora bien, es totalmente necesaria la diferencia enunciada en la tercera razón. Veámoslo con un ejemplo. Hasta la reforma tributaria del presidente Macron de 2018, el Derecho francés establecía la obligación de que los hogares fiscales dueños de un patrimonio que excediera cierto umbral pagaran un impuesto sobre la fortuna. Tal umbral fue variando; para simplificar digamos que estaba en un millón de euros. La única representación adecuada de tal deber es mediante la formulación puente (con un cuantificador prefijado).

Lo prueba el hecho siguiente. Imaginemos que todo francés con dinero en paraísos fiscales es dueño de un patrimonio superior a un millón de euros. ¿Concluiremos que en Francia es obligatorio que quienes tengan dinero en paraísos fiscales paguen el impuesto sobre la fortuna? ¡No! Aunque de hecho en Francia resulta que quienes tienen dinero en paraísos fiscales están obligados a pagar impuesto sobre la fortuna, no es verdad que en Francia sea obligatorio que quienes tengan dinero en paraísos fiscales estén sujetos a ese tributo. Por lo tanto se precisa la diferencia entre lo que es normativo (la formulación puente) y lo que es un hecho derivado, la formulación insular.

Por consiguiente, sí, es cierto: hay que abrazar la concepción puente, no la insular. Pero entonces surge una dificultad. Quitando el cuantificador (por mor de la simplificación) y aplicando la regla de instanciación, admitimos, en virtud del precepto legislativo que $\mathrm{o}(\mathrm{A} \rightarrow \mathrm{B})$, donde «A» significa «Lucas es dueño de más de un millón de euros» $y$ «B» significa "Lucas paga impuesto sobre la fortuna». $Y$ supongamos que, de hecho, se cumple A, o sea es un hecho (un bruto dato fáctico) que Lucas es dueño de más de un millón de euros. Tócanos inferir que está obligado a pagar el impuesto sobre la fortuna. ¿Cómo extraemos tal conclusión?

Justamente es el MPD lo único que nos permite extraer, de la obligación preceptuada por el legislador más el hecho bruto de que Lucas es dueño de más de un millón de euros, la conclusión deóntica de que Lucas debe pagar impuesto sobre la fortuna.

Abrazando la concepción puente (única aceptable por las tres razones recién aducidas), dado el precepto tributario del legislador y dado también el cumplimiento fáctico de la prótasis, ¿cómo, sin MPD, piensa Moreso extraer la conclusión de que Lucas deber pagar el impuesto?

Concluyo mi respuesta expresando el placer que me ha producido este intercambio, debatiendo entre académicos que compartimos referencias comunes, un utillaje conceptual y una metodología analítica y lógica.

\section{Bibliografía}

ERGEC, R. (2002). «La responsabilité du fait de la carence législative», en Mélanges Philippe Gérard, Bruselas: Bruylant, p. 287.

HART, H.L.A. (1961). The Concept of Law. Oxford: Clarendon Law Series

FIGUERUELO BURRIEZA, Á. (1993). «La incidencia positiva del Tribunal Constitucional en el Poder Legislativo». Revista de estudios políticos, № 81, pp. 47-72

FREEMAN, M. \& NAPIER, A. (2009). Law and anthropology. Oxford U. P. (Serie Current legal issues, $\mathrm{N}^{0}$ 12.)

JACKSON, F. \& PARGETTER, R. (1986). "Oughts, options, and actualism», Philosophical Review 95/2, pp. 233-255 
KELSEN, H. (1972). La théorie pure du droit, Paris: Dalloz

KIRKPATRICK, J. (2014). «Exit out of Athens? Migration and Obligation in Plato's Crito», Political Theory 43/3. DOI 10.1177/0090591714541875, cons. 2018-08-21

LLOYD, S. A. (2009). Morality in the Philosophy of Thomas Hobbes: Cases in the Law of Nature. Cambridge U. P.

NIETO, A. (2000). El arbitrio judicial. Ariel

PEÑA, L. (2013). "Una fundamentación jusnaturalista de los derechos humanos», Bajo Palabra, II Época, № 8, pp. 47-84. ISSN 1576-3935

(2016). «El bien público, más allá de la justicia», en Justicia ¿para todos? Perspectivas filosóficas, ed. por D. Rodríguez-Arias, J. Maiso \& C. Heeney. Madrid: Plaza y Valdés, pp. 31-40

PRICE, R. (ed.) (1996). Maroon Societies: Rebel Slave Communities in the Americas. John Hopkins U.P. ISBN 9780801854965

SANDEL, M. (1998). Liberalism and the Limits of Justice. Cambridge U.P., $2^{\mathrm{a}}$ ed.

SOLNICK, S. \& HEMENWAY, D. (1998). «ls more always better?: A survey on positional concerns», Journal of Economic Behavior \& Organization, Vol. 37, pp. 373-383

TURCHIN, P. (2013). "History tells us where the wealth gap leads», Aeon, disp. en https://aeon.co/essays/history-tells-us-where-the-wealth-gap-leads, acc. 201808-08. 